\title{
Localization of the inhibitory site(s) of pentosan polysulphate in blood coagulation
}

Citation for published version (APA):

Wagenvoort, R., Hendrix, H., Soria, C., \& Hemker, H. C. (1988). Localization of the inhibitory site(s) of pentosan polysulphate in blood coagulation. Thrombosis and Haemostasis, 60(2), 220-225.

https://doi.org/10.1055/s-0038-1647033

Document status and date:

Published: 01/01/1988

DOI:

10.1055/s-0038-1647033

Document Version:

Publisher's PDF, also known as Version of record

\section{Please check the document version of this publication:}

- A submitted manuscript is the version of the article upon submission and before peer-review. There can be important differences between the submitted version and the official published version of record.

People interested in the research are advised to contact the author for the final version of the publication, or visit the DOI to the publisher's website.

- The final author version and the galley proof are versions of the publication after peer review.

- The final published version features the final layout of the paper including the volume, issue and page numbers.

Link to publication

\footnotetext{
General rights rights.

- You may freely distribute the URL identifying the publication in the public portal. please follow below link for the End User Agreement:

www.umlib.nl/taverne-license

Take down policy

If you believe that this document breaches copyright please contact us at:

repository@maastrichtuniversity.nl

providing details and we will investigate your claim.
}

Copyright and moral rights for the publications made accessible in the public portal are retained by the authors and/or other copyright owners and it is a condition of accessing publications that users recognise and abide by the legal requirements associated with these

- Users may download and print one copy of any publication from the public portal for the purpose of private study or research.

- You may not further distribute the material or use it for any profit-making activity or commercial gain

If the publication is distributed under the terms of Article $25 \mathrm{fa}$ of the Dutch Copyright Act, indicated by the "Taverne" license above, 


\title{
Localization of the Inhibitory Site(s) of Pentosan Polysulphate in Blood Coagulation
}

\author{
R. Wagenvoord, H. Hendrix, C. Soria*, and H. C. Hemker \\ From the Biomedical Center, Department of Biochemistry, Maastricht, The Netherlands, \\ and the Laboratoire d'Hématologie Lariboisière*, Dept. of Prof. J. Caen, Paris, France
}

\author{
Key words \\ Pentosan polysulphate - Blood coagulation
}

\section{Summary}

We studied the inhibitory effect of pentosan polysulphate (PPS, Hémoclar ${ }^{(B)}$ ) on thrombin formation in blood coagulation. In contrast to a current hypothesis (1) the antithrombin III independent effect of PPS on blood coagulation is not caused by preventing the binding of the factors IX, IX $, \mathrm{X}, \mathrm{X}_{\mathrm{a}}, \mathrm{VIII}, \mathrm{V}, \mathrm{V}_{\mathrm{a}}$ and II onto procoagulant phospholipids.

We investigated the activation by thrombin of factors $I, V$ and VIII. A strong inhibitory effect of PPS on factor VIII activation could be observed. Inhibition of the activation of factor $V$ to the same extent requires about 30 -fold higher concentrations of PPS, whereas the activation (clotting) of fibrinogen is not inhibited. The effect of PPS on factor VIII $_{a}$ is two-fold: A) it inhibits its formation and B) it inhibits its function probably by the formation of a factor VIII $_{\mathrm{al}}$-PPS complex.

Prothrombinase, constituted of purified factors $X_{a}, V_{a}$ and phospholipids was not inhibited by PPS, neither were incomplete forms of this enzyme, lacking phospholipids or factor $\mathrm{V}_{\mathrm{a}}$. The complete factor $\mathrm{X}$ activating enzyme (factors $\mathrm{IX}_{\mathrm{a}}, \mathrm{VIII}_{\mathrm{a}}$ and phospholipids), however, was strongly inhibited, but incomplete forms, lacking factor VIII, were not. The inhibition of the complete enzyme can be explained by reversible binding of PPS to factor VIII $_{a}$ (causing an inhibition of its function) and it is not an effect on the enzymatic function of the complete enzyme. On saturation of the enzyme with an excess of factor $\mathrm{VIII}_{\mathrm{a}}$ no inhibition by PPS is noticed.

We postulate therefore that the antithrombin III independent inhibitory effect of PPS on thrombin generation on blood coagulation is by interaction with factor VIII $_{\mathrm{a}}$. This effect is additional to the heparin-like action of PPS, i.e. potentiation of the activity of antithrombin III and/or heparin cofactor II. At

This work was financially supported by the "Centre de Recherches Clin-Midy" and "La Fondation de France".

Abbreviations:

S2238, H-D-phenylalanyl-L-pipecolyl-L-arginine-p-nitro-anilidedihydrochloride; S2337, N-benzoyl-L-isoleucyl-L-glutamyl-(piperidyl)glycyl-L-arginine-p-nitroanilide hydrochloride; RVV-X, Factor X activator purified from Russell's viper venom; Tris, tris(hydroxymethyl)aminomethane; EDTA, ethylenediaminotetraacetic acid; PC, phosphatidyl choline; PS, phosphatidyl serine; DOPC, 1,2-dioleoyl-sn-glycero3-phosphocholine; DOPS, 1,2-dioleoyl-sn-glycero-3-phosphoserine; STI, soybean trypsin inhibitor; HSA, human serum albumin; PPS, pentosan polysulphate (Hémoclar); MES, 2-(N-Morpholino)ethane sulfonic acid; DEAE, diethylaminoethyl; QAE, quaternary aminoethyl; SP, sulfopropyl; APTT, Activated partial thromboplastin time.

Correspondence to: Prof. Dr. H. C. Hemker, Department of Biochemistry, Biomedical Center, University of Limburg, P. O. Box 616, 6200 MD Maastricht, The Netherlands concentrations attained during therapeutic use the action of pentosan polysulphate on factor $\mathrm{VIII}_{\mathfrak{a}}$ is the only one that will significantly inhibit the coagulation mechanism.

\section{Introduction}

Pentosan polysulphate (PPS) or Hémoclar ${ }^{(B)}$ is a mixture of polysaccharides that is obtained by sulphation of pentosans extracted from beech wood shavings (2). Its average molecular weight is 4,500 (2). Soria et al. (3) and Scully et al. (4) have shown that PPS shows some similarities with low molecular weight heparin as to its inhibitory effect on blood coagulation. Both compounds are dependent upon antithrombin III for factor $\mathrm{X}_{\mathrm{a}}$ and thrombin inhibiting activities $(3,4)$. Pentosan polysulphate also is a good activator of heparin cofactor II (2). Apart from that, PPS inhibits the partial thromboplastin time independently of antithrombin III $(1,3)$. Dunn et al. (5) have shown that both heparin and PPS increase the binding of fibrinogen to ADPtreated platelets. Fischer et al. (1) showed that PPS inhibits the factor $\mathrm{X}_{\mathrm{a}}$ generation in defibrinated plasma triggered by contact activation as well as by purified factor $I_{\mathrm{a}}$. This suggests that PPS does not act on the contact system, but interferes with factor $\mathrm{X}$ activation at the level of factor IX $_{\mathrm{a}}$. Both Ofosu et al. (6) and Walker and Esmon (7) have suggested that antithrombin III independent effects of heparin are due to inhibition of phospholipid binding. Fischer et al. (1) suggest that PPS acts by the same mechanism, presumably even more effective than heparin, because of its greater negative charge. Another suggested mechanism is inhibition of thrombin dependent factor $\mathrm{V}$ activation and thereby inhibiting the prothrombinase complex (8). From the literature it is clear that the site of inhibition of blood coagulation by PPS has not been determined unequivocally. Possible sites of action are: The activation of prothrombin by prothrombinase (factor $\mathrm{X}_{\mathrm{a}}$, factor $\mathrm{V}_{\mathrm{a}}$ and phospholipid) and the activation of factor $\mathrm{X}$ by its activating enzyme (factor $\mathrm{IX}_{\mathrm{a}}$, factor VIII $_{\mathrm{a}}$ and phospholipid). This inhibition might be mediated by either impairment of the binding of clotting factors to phospholipids or direct action on thrombin in the activation of one more of the factors I, V, and VIII.

\section{Materials and Methods}

\section{Materials}

Human congenital factor VIII deficient plasma was a gift from $T$. Repucci, Centre de Transfusion, Liège, Belgium. The plasma was from a patient with less than $1 \%$ factor VIII. The blood $(450 \mathrm{ml})$ was collected in a bag containing CPDA-formula $1(63 \mathrm{ml}$, containing $2 \mathrm{~g}$ dextrose monohydrate, $1.66 \mathrm{~g}$ sodium citrate, $206 \mathrm{mg}$ citric acid, $158 \mathrm{mg}$ sodium acid phosphate, $17.3 \mathrm{mg}$ adenine). The blood was centrifuged at $5,000 \times \mathrm{g}$ during $15 \mathrm{~min}$ at $4^{\circ} \mathrm{C}$. The plasma was frozen at $-80^{\circ} \mathrm{C}$ before use. Bovine factors $V$ and $V_{a}$ were a gift from Dr. T. Lindhout. S2337, S2238, RVV-X and human fibrinogen (grade L) were purchased from AB Kabi Diagnostica, Stockholm, Sweden. STI, HSA (essentially fatty acid free), heparin (sodium salt) and Echis carinatus venom were obtained from Sigma. Sephadex G50, DEAE-Sephadex and SP-Sephadex were from 
Pharmacia, Trasylol was from Bayer. Actin activated cephaloplastin reagent was from Dade Diagnostics and Reptilase from Boehringer Mannheim. Hémoclar was a gift of the Laboratoires Clin Midy, Paris, France.

All other reagents used, were of the highest grade commercially available.

\section{Proteins}

Bovine factor IX was purified according to Fujikawa et al. (9). Factor IX was prepared by incubating bovine factor IX with purified contact product $(10,11)$ according to Fujikawa et al. (12).

Bovine factors $X_{1}$ and $X_{2}$ were prepared according to Fujikawa et al. (13). The two forms of factor $X$ were well separated. In this study factor $X_{1}$ is used, which is not indicated further. No thrombin or factor $X_{2}$ could be detected in our factor $X$ preparations as determined with the chromogenic substrates S2238 and S2337, respectively. Bovine prothrombin was purified as described by Owen et al. (14). Thrombin was prepared by incubating $5 \mu \mathrm{M}$ prothrombin with $10 \mu \mathrm{M}$ phospholipid vesicles $(25 \%$ brain PS, $75 \%$ yolk PC), $10 \mathrm{mM} \mathrm{CaCl}, 30 \mathrm{nM}$ factor $\mathrm{X}_{\mathrm{a}}$ and $21 \mathrm{nM}$ factor $V_{a}$ during 40 min at $37^{\circ} \mathrm{C}$ in a buffer containing $40 \mathrm{mM}$ MES-Tris and $100 \mathrm{mM} \mathrm{NaCl}$ (pH 7.9). The reaction was terminated with $20 \mathrm{mM}$ EDTA. Then the mixture was diluted twice with water, brought to $\mathrm{pH} 6.5$ with MES and applied to an SP-Sephadex column $(5 \times 40 \mathrm{~cm})$, which was equilibrated with $20 \mathrm{mM}$ Tris-MES amd $50 \mathrm{mM} \mathrm{NaCl}$ ( $\mathrm{pH} \mathrm{6.5).} \mathrm{The}$ column was eluted with $250 \mathrm{ml}$ of $20 \mathrm{mM}$ Tris-MES, $200 \mathrm{mM} \mathrm{NaCl}$ (pH 6.5) to remove other prothrombin degradation products than thrombin. Finally the thrombin was eluted with a linear gradient of $(2 \times 500 \mathrm{ml})$

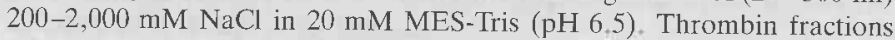
were dialysed against $175 \mathrm{mM} \mathrm{NaCl}$ and $50 \mathrm{mM}$ Tris- $\mathrm{HCl}(\mathrm{pH} \mathrm{7.9)}$.

Bovine factor VIII was purified according to Vehar and Davie (15) with the modifications of Van Dieijen et al. (16). To standardize the factor VIII, reference curves were made, using congenital factor VIII deficient plasma and normal pooled bovine plasma (16).

\section{Protein Concentrations}

The molar concentrations of factors IX, IX $, X_{1}, I I, V, V_{i}$ were calculated from their optical density at $280 \mathrm{~nm}$, their specific absorption and their molecular weight $(12,13,14,17)$.

The concentrations of activated clotting proteases also were determined spectrophotometrically from the amidolytic activity (18). Factor X was activated with $2 \mathrm{mg} / \mathrm{ml} \mathrm{RVV}-\mathrm{X}$ during $15 \mathrm{~min}$ at $37^{\circ} \mathrm{C}$ prior to functional measurement. Prothrombin was activated with Echis carinatus venom (19) and the ensuing thrombin was measured with S2238. Factor IX was activated with purified contact product $(10,11)$ and the factor IX $\mathrm{X}_{\mathrm{a}}$ was measured according to Tans et al. (20).

Factors $\mathrm{V}$ and $\mathrm{V}_{\mathrm{a}}$ were determined according Lindhout et al. (21).

Factor VIII was measured in two ways: $\mathrm{A}$ and $\mathrm{B}$.

A: To a mixture of $200 \mu \mathrm{l}$ phospholipid vesicles $(30 \mu \mathrm{M}, 75 \%$ DOPC and $25 \% \mathrm{DOPS}), \mathrm{CaCl}_{2}(5 \mathrm{mM})$ and factor $\mathrm{IX}_{\mathrm{a}}(150 \mathrm{nM})$ were added $50 \mu 1$ factor $\mathrm{X}(2 \mu \mathrm{M})$ and $\mathrm{CaCl}_{2}(5 \mathrm{mM})$. Fifteen seconds after the addition of the factor $X$, the activated factor VIII was added $(50 \mu 1)$. To stop the reaction samples of $200 \mu \mathrm{l}$ were pipetted (after $20 \mathrm{sec}$ ) into $700 \mu \mathrm{l}$ $20 \mathrm{mM}$ EDTA (in a cuvette). The formed factor $X_{a}$ was measured by addition of $100 \mu \mathrm{l} \mathrm{S} 2337(2 \mathrm{mM})$ and following substrate hydrolysis at $405 \mathrm{~nm}$. The whole procedure was done at $37^{\circ} \mathrm{C}$ and the mixtures used were prewarmed during at least $5 \mathrm{~min}$.

B: To a mixture of $250 \mu \mathrm{l} 40 \mu \mathrm{M}$ phospholipid vesicles (75\% DOPC and $25 \%$ DOPS), $10 \mathrm{mM} \mathrm{CaCl}_{2}, 100 \mathrm{nM}$ factor $\mathrm{IX}_{\mathrm{a}}$ were added $150-\mathrm{x} \mu \mathrm{l}$ buffer (see below). Then $x \mu 1$ factor $V_{1 I I}$ were added and after $30 \mathrm{sec}$ $100 \mu \mathrm{l}$ factor $\mathrm{X}(2 \mu \mathrm{M})$ to start the reaction. After 30 and $60 \mathrm{sec}$ reaction time $200 \mu 1$-samples were taken and the formed factor $X_{a}$ was measured.

In all cases corrections were made for $\$ 2337$ hydrolysis by thrombin and factor $\mathrm{X}_{\mathrm{a}}$ formation by factor IX $\mathrm{X}_{\mathrm{a}}$ in the absence of factor VIII

All experiments with the purified clotting factors were performed in a buffer containing $175 \mathrm{mM} \mathrm{NaCl}, 50 \mathrm{mM}$ Tris- $\mathrm{HCl}, 0.5 \mathrm{mg} / \mathrm{ml} \mathrm{HSA}$ (pH 7.9).

\section{Phospholipids and Phospholipid Vesicles}

DOPS was prepared from DOPC according to Comfurius and Zwaal (22). Vesicles were prepared by sonication of a phospholipid mixture of
25\% DOPS and 75\% DOPC using an MSE Mark II 150-Watt ultrasonic disintegrator, set at $9 \mu$ peak to peak amplitude, or by the ether-injection method according to Van de Steen et al. (23) and Deamer and Bangham (24). By injection of $2 \mathrm{ml}$ ether, containing $3 \mu \mathrm{mol} \mathrm{DOPC}$ and $1 \mu \mathrm{mol}$ DOPS into $4 \mathrm{ml}$ warm $\left(60^{\circ} \mathrm{C}\right)$ buffer $(175 \mathrm{mM} \mathrm{NaCl}, 50 \mathrm{mM}$ Tris- $\mathrm{HCl}$; $\mathrm{pH} 7.9$ ) large unilamellar vesicles were obtained. The vesicles were dialyzed against the same buffer to remove traces of ether. To concentrate the vesicles and to remove small vesicles which cannot be spun down, they were centrifuged at $6,000 \times \mathrm{g}$ during $10 \mathrm{~min}$. The supernatant was discarded, the pellet suspended into the same buffer and again the vesicles were spun down. Finally the pellet was taken up into a small amount of buffer. These vesicles were, used in the binding studies.

Phospholipid concentrations were determined by analysis of the phosphate content (25).

\section{Binding Experiments}

Binding of clotting factors to large unilamellar vesicles was measured in the following way. Clotting factors $(20-100 \mathrm{nM})$ were incubated in the presence of $5 \mathrm{mM} \mathrm{CaCl}$ with various concentrations of large-volumevesicles containing $25 \%$ DOPS and $75 \%$ DOPC. Then the vesicles were spun down $(10 \mathrm{~min}$ at $9,000 \times \mathrm{g})$ and the unbound clotting factors were measured in the supernatant.

\section{Clotting of Fibrinogen}

To $50 \mu \mathrm{l}$ human fibrinogen $(10 \mathrm{mg} / \mathrm{ml})$ were added $50 \mu \mathrm{l}$ buffer (175 mM NaCl, $50 \mathrm{mM}$ Tris- $\mathrm{HCl}(\mathrm{pH} 7.9), 0.5 \mathrm{mg} / \mathrm{ml} \mathrm{HSA}$ and if present $20 \mathrm{mM} \mathrm{CaCl} 2$ ). The reaction was started by the addition of $100 \mu \mathrm{I}$ thrombin $(20-80 \mathrm{nM})$. The clotting time was detected manually.

\section{Results}

\section{Binding Experiments}

In order to measure the effect of PPS on binding of clotting factors to phospholipid membranes we first determined the conditions under which without PPS, $50 \%$ of the factor would be bound. The effect of PPS on the binding of the different factors has been determined at a range of PPS concentrations $(0-20 \mu \mathrm{g} /$ $\mathrm{ml}$ ). In none of the cases PPS prevented binding of the clotting factor to the phospholipid membranes. PPS in many cases even slightly promotes this binding, an effect that is most pronounced for factors $X_{a}$ and $I X_{a}$. Table 1 shows the results for one PPS concentration. Because no inhibition of the binding could be shown under the above circumstances, the other data are not shown.

\section{Thrombin-Dependent Activation of Factors $V$ and VIII and Fibrinogen}

Fig. 1 shows the effect of PPS on the activation of factor VIII by $0.5 \mathrm{nM}$ thrombin. In the absence of PPS the maximal amount of factor $\mathrm{VIII}_{\mathrm{a}}$ is reached after about $3 \mathrm{~min}$ and then the amount slowly decreases. When PPS is present during the activation, the rate of factor $\mathrm{VIII}_{\mathrm{a}}$ formation strongly decreases with increasing PPS concentrations and the maximal amounts of factor VIII formed also are much lower. Half maximal inhibition of the activation is obtained at about $1 \mu \mathrm{g} / \mathrm{ml}$ of PPS. An amount of $0.5 \mathrm{nM}$ thrombin activates factor VIII only slowly. In Fig. 2 the factor VIII is activated with $50 \mathrm{nM}$ thrombin. The turnover numbers in both cases differ quite a lot. In Fig. 1 the number is 23-30 $\mathrm{min}^{-1}$, whereas it is in Fig. 2 about $800 \mathrm{~min}^{-1}$. From these numbers it can be calculated that after $1 \mathrm{~min}$ activation with $0.5 \mathrm{nM}$ thrombin not more than $2 \%$ of the factor VIII is activated.

The experiment of Fig. 1 is repeated with $2.5 \mathrm{mg} / \mathrm{ml}$ fibrinogen present in the factor VIII activating mixture. In that case the activation rate of factor VIII is decreased. To obtain a same 


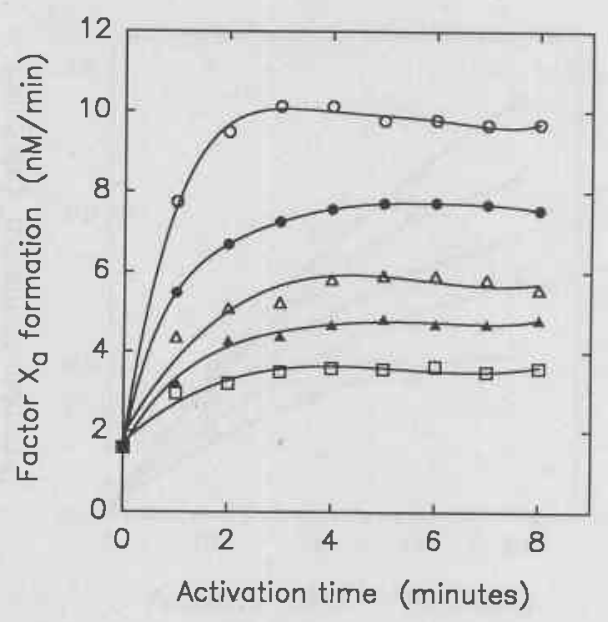

Fig. 1 Effect of PPS on the activation of factor VIII by thrombin. Factor VIII $(2 \mathrm{nM})$ was activated $\left(37^{\circ} \mathrm{C}\right)$ with $0.5 \mathrm{nM}$ thrombin in the presence of $5 \mathrm{mM} \mathrm{CaCl}_{2}$ and PPS in concentrations of $0(0), 0.5(\bullet), 1$ $(\triangle), 2(\Delta)$ and $4(\square) \mu \mathrm{g} / \mathrm{ml}$. The formed factor VIII $_{a}$ was measured after 1-8 min activation time: procedure $\mathrm{A}$, see Methods. Corrections were made for the inhibiting effect of PPS on the factor X-activating reaction itself. To determine this effect, independently from the effect on factor VIII activation, PPS was added to the factor $\mathrm{X}$ activating mixture in the required concentrations. Then factor VIII $(2 \mathrm{nM})$, activated for $4 \mathrm{~min}$ $\left(37^{\circ} \mathrm{C}\right)$ in the absence of PPS, was added to the reaction mixture and the rate of factor $\mathrm{X}$ activation measured

activation rate as in the absence of fibrinogen, about 2.5 times more thrombin is necessary. However, also with fibrinogen present, PPS still is a very potent inhibitor of factor VIII activation; $0.5,1,2$ and $4 \mu \mathrm{g} / \mathrm{ml}$ PPS cause inhibition percentages

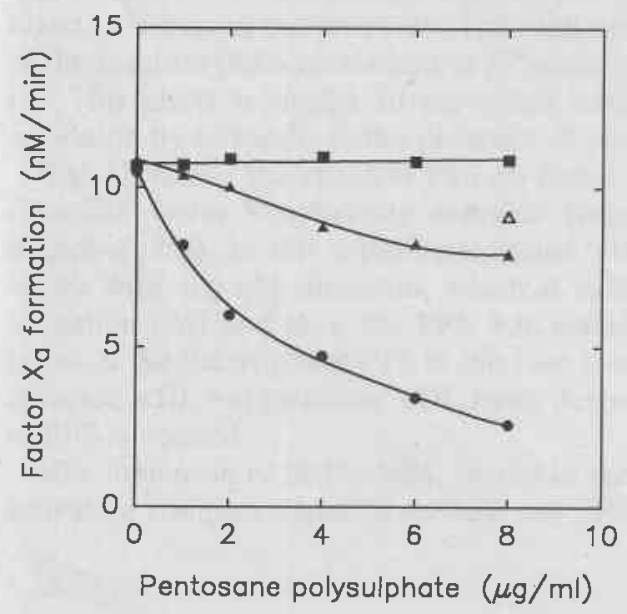

Fig. 2 Effect of PPS on activation of factor VIII with $50 \mathrm{nM}$ thrombin and effect of PPS on activated factor VIII. In case $(\boldsymbol{\Delta})$ the activation was started by mixing $20 \mu \mathrm{l}$ factor VIII $(12 \mathrm{nM})$ with $20 \mu \mathrm{l}$ thrombin $(100 \mathrm{nM}), \mathrm{CaCl}_{2}(10 \mathrm{mM})$. At $\mathrm{t}=30 \mathrm{sec} 20 \mu \mathrm{lPS}(0-24 \mu \mathrm{g} / \mathrm{ml})$ were added, making the final PPS concentrations as indicated in the figure. The PPS solution also contained $5 \mathrm{mM} \mathrm{CaCl}_{2}$ and $50 \mathrm{nM}$ thrombin to keep these concentrations constant after PPS addition. In case (-) the activation was started by addition of PPS together with thrombin. To $40 \mu \mathrm{l}$ factor VIII ( $6 \mathrm{nM}$ ) were added $20 \mu 1150 \mathrm{nM}$ thrombin, $15 \mathrm{mM} \mathrm{CaCl}_{2}$ and $0-24 \mu \mathrm{g} / \mathrm{ml}$ PPS. In both cases at $\mathrm{t}=60 \mathrm{sec} 5 \mu \mathrm{l}$-samples were taken and assayed for factor $\mathrm{VIII}_{\mathrm{a}}$ (Methods, procedure B). The open triangle $(\triangle)$ is the result of factor VIII activation with $50 \mathrm{nM}$ thrombin in the presence of $5 \mathrm{mM} \mathrm{CaCl}_{2}$ and absence of PPS during $30 \mathrm{sec}$. The control (ם) shows an experiment in which $5 \mu \mathrm{lPPS}(0-8 \mu \mathrm{g} / \mathrm{ml})$ were added to the factor VIII $_{\mathrm{a}}$ assay mixture and the factor VIII was activated with $50 \mathrm{nM}$ thrombin (in the presence of $5 \mathrm{mM} \mathrm{CaCl}_{2}$ ) during $60 \mathrm{sec}$
Table 1 The effect of PPS on binding of clotting factors to large volume phospholipid vesicles

\begin{tabular}{llcc}
\hline Factor & $\begin{array}{l}\text { Concentration } \\
(\mathrm{nM})\end{array}$ & $\begin{array}{l}\mathrm{C50} \\
(\mu \mathrm{M})\end{array}$ & $\begin{array}{l}\Delta \mathrm{B} \\
(\%)\end{array}$ \\
\hline $\mathrm{X}$ & 41 & 37 & +28 \\
$\mathrm{X}_{\mathrm{a}}$ & 59 & 17.5 & +37 \\
$\mathrm{IX}$ & 65 & 445 & +12 \\
$\mathrm{IX}_{\mathrm{a}}$ & 58 & 63 & +35 \\
$\mathrm{II}$ & 31 & 45 & +4 \\
$\mathrm{~V}$ & 96 & 600 & -5 \\
$\mathrm{~V}_{\mathrm{a}}$ & 20 & 12.6 & +17 \\
VIII & 50 & 47 & +1 \\
\hline
\end{tabular}

C50 is the phospholipid concentration at which the binding of the clotting factors in the absence of PPS is $50 \% . \Delta \mathrm{B}$ is the change in binding brought about by $5 \mu \mathrm{g} / \mathrm{ml}$ PPS. The binding of the eight clotting factors to the vesicles was measured at a range of phospholipid concentrations to determine the phospholipid concentration that causes a $50 \%$ binding of the clotting factor. At these phospholipid concentrations the effect of PPS was determined. Five $\mu \mathrm{g}$ PPS per $\mathrm{ml}$ were added to phospholipid-clotting factor-mixtures and the effect of the PPS on the binding was determined.

of $20,39,64$ and 81 , respectively. These numbers are similar to the values found in Fig. 1.

Fig. 2 shows an experiment in which factor VIII is activated with $50 \mathrm{nM}$ thrombin for $1 \mathrm{~min}$. Two cases were compared, firstly PPS was added before the addition of thrombin and secondly it was added $30 \mathrm{sec}$ after the addition of thrombin. Factor VIII $_{\mathrm{a}}$ was measured by diluting it 100 -fold in the factor $\mathrm{X}$ activating mixture ( $5 \mu \mathrm{l}$-sample). The control shows that the PPS present in the $5 \mu \mathrm{l}$ sample does not affect the factor $\mathrm{VIII}_{a}$-assay. When PPS is present during the whole minute it effectively inhibits, but when it is added at $30 \mathrm{sec}$ after the thrombin addition (then almost all factor VIII is activated; point $\triangle$ ) it has only a minimal effect. So we can conclude that PPS inhibits factor VIII activation, but hardly preformed factor VIII ${ }_{a}$, provided that the PPS is diluted afterwards.

The effect of PPS on factor $V$ activation is shown in Fig. 3. One can observe that PPS has only a slight inhibitory effect. The effect of PPS on factor $V$ activation by thrombin is, decreasing the activation rate and not inhibiting factor $V_{a}$. The factor $V_{a}$ activity after $2 \mathrm{~h}$ activation time was the same for all PPS concentrations. In Fig. 3 the plateau after $2 \mathrm{~h}$ was at $1.6 \mathrm{nM} \mathrm{min}{ }^{-1}$. Half maximal inhibition requires more than $30 \mu \mathrm{g} / \mathrm{ml}$ of PPS.

The effect of PPS on fibrinogen clotting by thrombin was less then $20 \%$ under all conditions either in the absence or presence of $5 \mathrm{mM} \mathrm{CaCl}_{2}$. In the absence of $\mathrm{CaCl}_{2}, 10$ and $40 \mathrm{nM}$ thrombin caused clotting times of 196 and $119 \mathrm{sec}$, which were not prolonged by $50 \mu \mathrm{g} / \mathrm{ml}$ PPS and only for a few seconds with much higher PPS concentrations (up to $250 \mu \mathrm{g} / \mathrm{ml}$ ) representing an inhibition of less than $10 \%$. In the presence of $5 \mathrm{~m} \mathrm{M} \mathrm{CaCl}_{2}$, the clotting times were 152 and $39.5 \mathrm{sec}$, using 10 and $40 \mathrm{nM}$ thrombin, respectively. Also in this case PPS hardly had an effect. No change in the clotting times was observed at less than $20 \mu \mathrm{g} / \mathrm{ml}$ PPS and only some prolongation of the clotting time could be noticed at $50 \mu \mathrm{g} / \mathrm{ml}$ PPS: the above mentioned clotting times were 20 and $4 \mathrm{sec}$ longer, respectively, representing an inhibition of $10-20 \%$.

\section{The Effect of PPS of the Activation of Factors II and X}

We have studied the effect of PPS on the prothrombin activating complex. In the absence of phospholipid PPS has no effect on prothrombin activation, however, when phospholipids are present the activation reaction is somewhat stimulated by PPS (two-fold). PPS does not affect the complete prothrombin activat- 


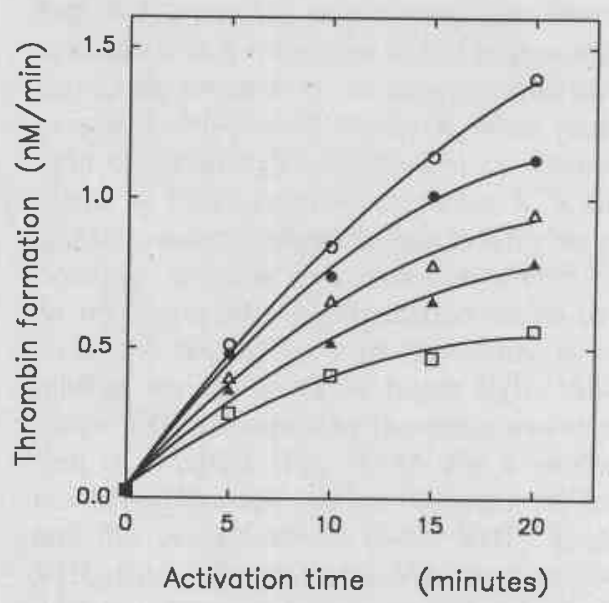

Fig. 3 The effect of PPS on activation of factor $V$ by thrombin. Factor $V$ $(42 \mathrm{nM})$ was activated with $0.5 \mathrm{nM}$ thrombin, in the presence of $5 \mathrm{mM}$ $\mathrm{CaCl}_{2}$ and PPS in concentrations of $0(\mathrm{O}), 4(\bullet), 8(\triangle), 16(\Delta)$ and $32(\square)$ $\mu \mathrm{g} / \mathrm{ml}$. To stop further activation, the mixture was diluted 1,000 -fold in $5 \mathrm{mM} \mathrm{CaCl}_{2}$, before measuring the factor $\mathrm{V}_{\mathrm{a}}$ formed

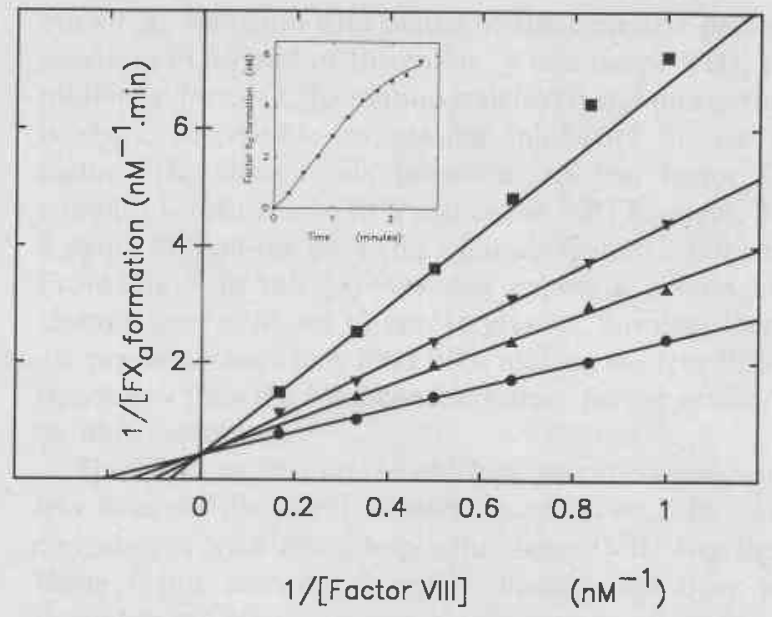

Fig. 5 Factor $\mathrm{X}$ activation by the complete factor $\mathrm{X}$ activating complex in the absence and presence of PPS. The reaction vessel contained $3 \mathrm{pM}$ factor $\mathrm{IX}_{\mathrm{a}}, 5 \mathrm{mM} \mathrm{CaCl}, 20 \mu \mathrm{M}$ phospholipids, $100 \mathrm{nM}$ thrombin and PPS, present in concentrations of $0(\bullet), 0.5(\boldsymbol{\Delta}), 1(\boldsymbol{\nabla})$ and $2(\boldsymbol{\square}) \mu \mathrm{g} / \mathrm{ml}$. Before starting the reaction all components were preincubated during $5 \mathrm{~min}$ at $37^{\circ} \mathrm{C}$. Then $0.2 \mu \mathrm{M}$ factor $\mathrm{X}$ was added $(\mathrm{t}=0 \mathrm{~min})$ and at $\mathrm{t}=$ $1 \mathrm{~min}$ the factor VIII (1-6 nM, i. e. 1.45-8.72 U/ml). Samples were taken at $t=1.25 \mathrm{~min}$ and assayed for factor $\mathrm{X}_{\mathrm{a}}$. The inset shows that factor $\mathrm{X}$ activation was linear from 5 to $90 \mathrm{sec}$ after the factor VIII addition. The $\mathrm{V}_{\max }$ was $2.406 \mathrm{nM} \mathrm{FX}_{\mathrm{a}}$ min $^{-1}$

the factor VIII ${ }_{a}$ concentration as is shown in Fig. 5. Fig. 5 is a double reciprocal plot of the factor $X_{a}$ formation against the factor VIII concentration at different PPS concentrations. Straight lines were obtained, which all cross the $y$-axis at the same point (0.416 $\mathrm{nM}^{-1} \mathrm{~min}$, i. e. $2.406 \mathrm{nM}$ factor $\mathrm{X}_{\mathrm{a}}$ formed per min). Thus at infinite factor VIII $_{a}$ concentration PPS does not inhibit the complete factor $\mathrm{X}$ activating complex.

\section{Discussion}

The binding experiments described in this article show that in no case PPS prevents binding of a clotting factor to procoagulant phospholipids. So one may conclude that inhibiting effect of PPS in blood coagulation is not caused by preventing the formation of the prothrombin or factor $\mathrm{X}$ activating complexes. There even exists a stimulating effect of PPS on binding of factors IX $X_{a}$ and $X_{a}$ and to a lesser extent on binding of factors IX, X and $V_{a}$ to phospholipid membranes (Table 1), the reason for this phenomenon is not yet clear. This increased binding, moreover, leads to higher enzymatic activities. PPS stimulates - in the presence of phospholipids - the activation of factors X (Fig. 4A) and II by
Fig. 4 Effect of PPS on the factor $\mathrm{X}$ activation by factor $\mathrm{IX}_{a}$ Frame A: Activation of factor $\mathrm{X}$ by factor $\mathrm{IX}_{\mathrm{a}}$ in the absence $(\mathbf{O})$ and presence $(\boldsymbol{\Lambda})$ of phospholipids. The reaction mixture contained $1 \mu \mathrm{M}$ factor $\mathrm{IX}_{\mathrm{a}}, 5 \mathrm{mM} \mathrm{CaCl}, 0-10 \mu \mathrm{g} / \mathrm{ml} \mathrm{PPS}$ and if present $20 \mu \mathrm{M}$ phospholipids. In the absence of phospholipids the reaction was started with $8 \mu \mathrm{M}$ factor $\mathrm{X}$ and in their presence with $2 \mu \mathrm{M}$ factor $\mathrm{X}$. Samples were taken after 10,20 and $30 \mathrm{~min}$ reaction time and assayed for factor $\mathrm{X}_{\mathrm{a}}$. Frame B: Activation of factor $\mathrm{X}$ by the complete factor $\mathrm{X}$ activating complex. The reaction mixture contained $50 \mathrm{nM}$ factor $\mathrm{IX}_{\mathrm{a}}, 100 \mathrm{nM}$ thrombin, $5 \mathrm{mM}$ $\mathrm{CaCl}_{2}, 20 \mu \mathrm{M}$ phospholipids, $15 \mathrm{pM}$ factor VIII (added at $\mathrm{t}=0$ sec) and $0-10 \mu \mathrm{g} / \mathrm{ml}$ PPS $+1 \mu \mathrm{M}$ factor $\mathrm{X}$, which were added together at $t=30 \mathrm{sec}$. Samples were taken at $t=60$ and $90 \mathrm{sec}$ and assayed for factor $\mathrm{X}_{\mathrm{a}}$. In all cases before starting the reaction of the components were preincubated at $37^{\circ} \mathrm{C}$ for $5 \mathrm{~min}$

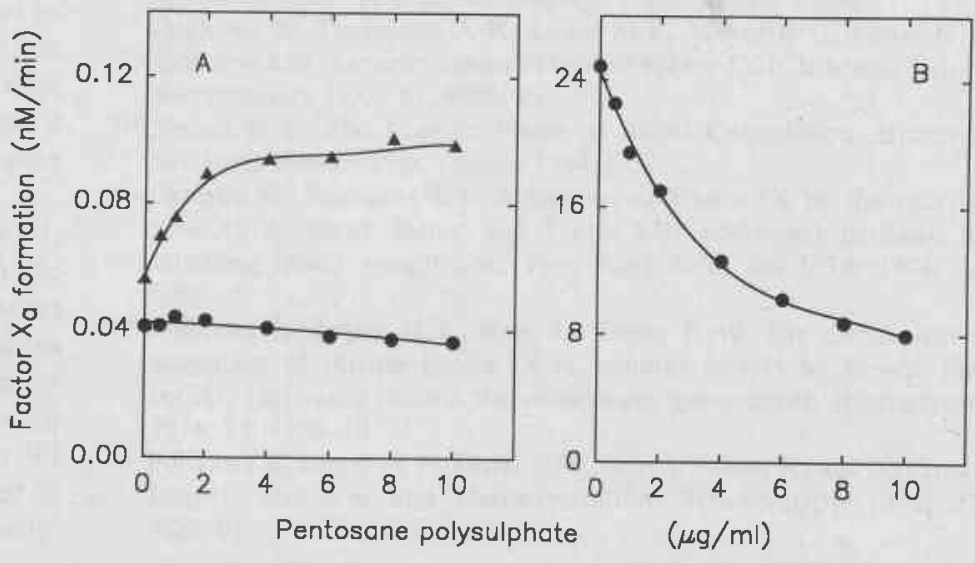


factors $\mathrm{IX}_{\mathrm{a}}$ and $\mathrm{X}_{\mathrm{a}}$, respectively. The increased enzymatic activity very likely is a reflection of the higher local concentration of the activation enzyme on the phospholipid membrane surface. In the presence of factor $V_{a}$, factor $X_{a}$ binds much tighter to a phospholipid membrane $(27,28)$ than in its absence, so in the presence of factor $V_{a}$ PPS has no effect: factor $X_{a}$ is almost completely bound and thus more binding leading to a higher enzymatic activity is not possible. Anyhow the conclusion of Fischer et al. (1) that PPS acts by inhibiting complex formation seems to be refuted.

In the second part of this study it became clear that PPS inhibits on the level of factor VIII. About $85 \%$ inhibition of factor VIII activation by thrombin was shown at a PPS concentration of $4 \mu \mathrm{g} / \mathrm{ml}$ (Fig. 1). In Fig. 1 probably an equilibrium is reached after a few minutes between the formation of factor VIII $_{a}$ and the breakdown of factor $\mathrm{VIII}_{\mathrm{a}}$. If the formation of factor VIII $_{\mathrm{a}}$ from a large factor VIII pool is slow, than the large pool does not decrease in size, so factor $\mathrm{VIII}_{\mathrm{a}}$ formation will continue for several minutes with the same speed. In that case a plateau is reached depending on formation and breakdown of factor $\mathrm{VIII}_{\mathrm{a}}$. When factor VIII formation is diminished, two effects may be noticed, the initial rate of factor $\mathrm{VIII}_{\mathrm{a}}$ formation is lower and the plateau is on a lower level. So PPS has two effects, it decreases the initial activation rate and it causes a lower steady state level of factor $\mathrm{VIII}_{\mathrm{a}}$.

The data from Fig. 1 may be interpreted in two ways. Either factor VIII $_{\mathrm{a}}$ is inhibited by PPS or the activation of factor VIII by thrombin is inhibited by this drug. Fig. 2 shows that PPS inhibits factor VIII activation by thrombin, but does not inactivate preformed factor VIII $_{a}$. Combining the results of Figs. 2 and $4 \mathrm{~B}$ it is clear that although PPS does not inactivate factor $\mathrm{VIII}_{\mathrm{a}}$, it inhibits the function of factor $\mathrm{VIII}_{\mathrm{a}}$. Factor $\mathrm{VIII}_{\mathrm{a}}$ probably is reversibly inhibited by binding to PPS. When a PPS-factor $\mathrm{VIII}_{\mathrm{a}}$ complex is diluted sufficiently (100-fold, Fig. 2) factor $\mathrm{VHI}_{\mathrm{a}}$ gets back its function.

Factor $\mathrm{V}$ activation by thrombin also can be inhibited by PPS, however, about 30 -fold higher concentrations of PPS are required to obtain the same inhibiting effect (Fig. 3). Clotting of fibrinogen by thrombin is hardly inhibited and only then when the PPS concentration is very high. Probably there is no interaction between fibrinogen and PPS, for, as was shown, fibrinogen does not prevent the inhibitory effect of PPS on factor VIII activation by thrombin.

In Figs. 4-5 we showed the effect of PPS on the complete and incomplete factor $\mathrm{X}$ activating complex. The most important result is the inhibiting effect of PPS on the complete factor $\mathrm{X}$ activating complex (Fig. 4B). Under the conditions of Fig. 4B half maximal inhibition is caused by $4 \mu \mathrm{g} / \mathrm{ml}$ PPS, but from Fig. 5 it is clear that the percentage of inhibition depends on both the PPS concentration and the factor $\mathrm{VIII}_{\mathrm{a}}$ concentration. On extrapolation to infinite factor VIII $_{\mathrm{a}}$ concentration no inhibition is found at any PPS concentration, which means that it is not the factor $X$ activating complex as such that is inhibited by PPS, but one of its components: factor $\mathrm{VIII}_{\mathrm{a}}$. When factor $\mathrm{VIII}_{\mathrm{a}}$ is present in excess no inhibition of the complex by PPS is found. Thus PPS has a twofold effect, it inhibits factor VIII activation by thrombin and it inhibits factor VIII $_{a}$ action in the factor $\mathrm{X}$ activating complex probably by reversible binding to factor $\mathrm{VIII}_{\mathrm{a}}$.

On basis of the result that PPS mainly acts on factor VIII activation, one can predict that PPS should have an effect on the APTT. On starting blood coagulation by contact activation factor $\mathrm{XI}_{\mathrm{a}}$ activates factor $\mathrm{IX}$, factor $\mathrm{IX}_{\mathrm{a}}$ then slowly activates factor $\mathrm{X}$ and finally factor $\mathrm{X}_{\mathrm{a}}$ slowly activates prothrombin to thrombin, which initially is formed in trace amounts. These small amounts of thrombin activate factor VIII (and also factor V) slowly. When some factor VIII $_{\mathrm{a}}$ is present, the complete factor X activating complex is formed, which will activate factor $\mathrm{X}$ rapidly.
Factor $\mathrm{X}_{\mathrm{a}}$ will form with factor $\mathrm{V}_{\mathrm{a}}$ the complete prothrombinase, resulting in a burst of thrombin. When factor VIII $_{a}$ formation is inhibited, factor $\mathrm{X}_{\mathrm{a}}$ formation is delayed and moreover factor IX is more susceptible to plasma inhibitors in the absence of factor VIII $_{\mathrm{a}}$ than in its presence, so less factor $\mathrm{X}$ activating complex is formed. So PPS makes the APTT longer. The effect of $2 \mu \mathrm{g} / \mathrm{ml}$ PPS on the APTT in a human system is not very high (3). From Fig. 1 in ref. (3) one can expect a prolongation of the clotting time of about $10 \mathrm{sec}$. In plasma, however, many proteins are present, which may bind PPS, making the free PPS concentration lower than the total concentration. So the effect of PPS may be underestimated.

The effect of PPS on the extrinsic blood coagulation should be less than on the intrinsic blood coagulation. On starting blood coagulation with thromboplastin, factor $\mathrm{VII}_{\mathrm{a}}$ together with the tissue factor activates factor $\mathrm{X}$ directly and trace amounts of thrombin will activate factor $V$ (not very much inhibited by PPS), so the complete prothrombinase is formed independently of the factor $\mathrm{X}$ activating complex.

We conclude that the main antithrombin III independent inhibitory action of PPS is due to its effects on factor VIII $_{a}$. Therapeutic concentrations of PPS will not rise higher than $2 \mu \mathrm{g} /$ $\mathrm{ml}$ (1) and at this concentration the only antithrombin III independent action on blood coagulation is that on factor VIII $_{\mathrm{a}}$

\section{References}

1 Fischer A M, Barrowcliffe T W, Thomas D P. A Comparison of pentosan polysulphate (SP 54) and heparin. I: Mechanism of action on blood coagulation. Thromb Haemostas 1982; 47: 104-8.

2 Scully M F, Ellis V, Kakkar V V. Pentosan polysulphate: Activation of heparin cofactor II or antithrombin III according to molecular weight fractionation. Thromb Res 1986; 41: 489-99.

3 Soria C, Soria J, Rijckewaart J J, Holmer E, Caen J P. Anticoagulant activities of a pentosane polysulphate: Comparison with standard heparin and a fraction of low molecular weight heparin. Thromb Res $1980 ; 19: 455-63$

4 Scully M F, Weerasinghe K M, Ellis V, Djazaeri B, Kakkar V V. Anticoagulant and antiheparin activities of a pentosan polysulphate. Thromb Res 1983; 31: 87-97.

5 Dunn F, Soria J, Soria C, Thomaidis A, Tobelem G, Caen P. Fibrinogen binding on human platelets. Influence of different heparins and pentosane polysulphate. Thromb Res 1983; 29: 141-8.

6 Ofosu F, Blajchman M A, Hirsh J. The inhibition by heparin of the intrinsic pathway activation of factor $\mathrm{X}$ in the absence of antithrombin III. Thromb Res 1980; 20: 391-403.

7 Walker $\mathbf{F ~ J}$, Esmon C T. Interactions between heparin and factor $\mathrm{X}_{\mathrm{a}}$ Inhibition of prothrombin activation. Biochim Biophys Acta 1979; 585: $405-15$

8 Ofosu F A, Sie P, Modi G J, Fernandez F, Buchanan M R, Blajchman M A, Boneu B, Hirsh J. The inhibition of thrombin dependent positive-feedback reactions is critical to the expression of the anticoagulant effect of heparin. Biochem J 1987; 243: 579-88.

9 Fujikawa K, Thompson A R, Legaz M E, Meyer R G, Davie E W. Isolation and characterization of bovine Factor IX (Christmas factor). Biochemistry 1973; 12: 4938-45.

10 Nossel H L. The Contact Phase of Blood Coagulation. Blackwell Scientific Publications, Oxford 1964.

11 Østerud B, Rapaport S I. Activation of Factor IX by the reaction product of tissue factor and Factor VII: additional pathway for initiating blood coagulation. Proc Natl Acad Sci USA 1974; 12: $5260-4$.

12 Fujikawa K, Legaz M E, Kato H, Davie E W. The mechanism of activation of bovine Factor IX (Christmas factor) by bovine Factor $\mathrm{XI}_{\text {a }}$ (activated plasma thromboplastin antecedent). Biochemistry 1974; 13: 4508-16.

13 Fujikawa K, Legaz M E, Davie E W. Bovine Factor $\mathrm{X}_{1}$ and $\mathrm{X}_{2}$ (Stuart factor). Isolation and characterization. Biochemistry 1972; 11: 4882-91, 
14 Owen W G, Esmon C T, Jackson C M. The conversion of prothrombin to thrombin. I. Characterization of the reaction products formed during the activation of bovine prothrombin. J Biol Chem 1974; 249 : $594-605$.

15 Vehar G A, Davie E W. Preparation and properties of bovine factor VIII (antihemophilic factor). Biochemistry 1980; 19: 401-10.

16 Van Dieijen G, van Rijn J L M L, Govers-Riemslag J W P, Hemker H $\mathrm{C}$, Rosing $J$. Assembly of the intrinsic factor $\mathrm{X}$ activating complex: Interations between factor $\mathrm{IX}_{\mathrm{a}}$, factor $\mathrm{VIII}_{\mathrm{a}}$ and phospholipid. Thromb Haemostas 1985; 53: $396-400$.

17 Nesheim E M, Myrmel K H, Hibbard L, Mann K G. Isolation and characterization of single chain bovine Factor V. J Biol Chem 1979; 254: $508-17$.

18 Lottenberg R, Christensen U, Jackson C M, Coleman P L. Assay of Coagulation Proteases Using Peptide Chromogenic and Fluorogenic Substrates. In: Methods in Enzymology. Lorand L (ed). 1981; 80: 341-61.

19 Van de Waart P, Bruls H, Hemker H C, Lindhout T. Interactions of Bovine Blood Clotting Factor $V_{a}$ and Its Subunits with Phospholipid Vesicles. Biochemistry 1983; 22: 2427-32.

20 Tans G, Janssen-Claessen T, van Dieijen G, Hemker H C, Rosing J. Activation of Factor IX by Factor $\mathrm{XI}_{\mathrm{a}}-\mathrm{A}$ spectrophotometric assay for Factor IX in human plasma. Thromb Haemostas 1982; 48: 127-32.

21 Lindhout T, Govers-Riemslag J W P, Van de Waart P, Rosing J, Hemker $\mathrm{H}$ C. Factor $\mathrm{V}_{\mathrm{a}}-$ Factor $\mathrm{X}_{\mathrm{a}}$ interaction. Effects of phos- pholipid vesicles of varying composition. Biochemistry 1982; 21: 5494-502.

22 Comfurius P, Zwaal R F A. The enzymatic synthesis of phosphatidyl serine and purification by CM-cellulose column chromatography. Biochim Biophys Acta 1977; 488: 36-42.

23 Van der Steen A T M, De Jong W A C, De Kruijff B, Van Deenen L L M. Lipid dependence of glycophorin-induced transbilayer movement of lysophosphatidyl choline in large unilamellar vesicles. Biochim Biophys Acta 1981; 647: 63-72.

24 Deamer D, Bangham A D. Large volume liposomes by an ether vaporization method. Biochim Biophys Acta 1976; 443: 629-34.

25 Böttcher C J F, Van Gent C M, Pries C. A rapid and sensitive submicrophosphorus determination. Anal Chim Acta 1961; 24: 203-7.

26 Baruch D, Lindhout T, Wagenvoord R, Hemker H C. Inhibition of Thrombin Catalyzed Reactions in Blood Coagulation and Platelet Activation by Heparin Fractions in the Absence of Antithrombin III. Haemostasis 1986; 16: 71-81.

27 Nelsestuen G L, Broderius M. Interaction of prothrombin and blood clotting Factor $X$ with membranes. Biochemistry 1977; 16: 4172-7.

28 Bloom J W, Nesheim M E, Mann K G. Phospholipid binding properties of bovine Factor $\mathrm{V}$ and Factor $\mathrm{V}_{\mathrm{a}}$. Biochemistry 1979; 18: $4419-25$.

Received January 14, 1988 Accepted after revision May 31, 1988 


\title{
Localization of the Inhibitory Site(s) of Pentosan Polysulphate in Blood Coagulation
}

\author{
R. Wagenvoord, H. Hendrix, C. Soria*, and H. C. Hemker \\ From the Biomedical Center, Department of Biochemistry, Maastricht, The Netherlands, \\ and the Laboratoire d'Hématologie Lariboisière*, Dept. of Prof. J. Caen, Paris, France
}

\section{Key words}

Pentosan polysulphate - Blood coagulation

\section{Summary}

We studied the inhibitory effect of pentosan polysulphate (PPS, Hémoclar ${ }^{(\mathbb{B})}$ ) on thrombin formation in blood coagulation. In contrast to a current hypothesis (1) the antithrombin III independent effect of PPS on blood coagulation is not caused by preventing the binding of the factors IX. IX $, \mathrm{X}, \mathrm{X}_{\mathrm{a}}, \mathrm{VIII}, \mathrm{V}, \mathrm{V}_{\mathrm{a}}$ and II onto procoagulant phospholipids.

We investigated the activation by thrombin of factors $I, V$ and VIII. A strong inhibitory effect of PPS on factor VIII activation could be observed. Inhibition of the activation of factor $V$ to the same extent requires about 30 -fold higher concentrations of PPS, whereas the activation (clotting) of fibrinogen is not inhibited. The effect of PPS on factor VIII ${ }_{a}$ is two-fold: A) it inhibits its formation and B) it inhibits its function probably by the formation of a factor $\mathrm{VIII}_{2}$-PPS complex.

Prothrombinase, constituted of purified factors $X_{a}, V_{a}$ and phospholipids was not inhibited by PPS, neither were incomplete forms of this enzyme, lacking phospholipids or factor $\mathrm{V}_{\mathrm{a}}$. The complete factor $\mathrm{X}$ activating enzyme (factors $\mathrm{IX}_{\mathrm{a}}, \mathrm{VIII}_{\mathrm{a}}$ and phospholipids), however, was strongly inhibited, but incomplete forms, lacking factor VIII, were not. The inhibition of the complete enzyme can be explained by reversible binding of PPS to factor VIII $_{\mathrm{a}}$ (causing an inhibition of its function) and it is not an effect on the enzymatic function of the complete enzyme. On saturation of the enzyme with an excess of factor VIII $a$ no inhibition by PPS is noticed.

We postulate therefore that the antithrombin III independent inhibitory effect of PPS on thrombin generation on blood coagulation is by interaction with factor VIII $\mathrm{a}_{\mathrm{a}}$. This effect is additional to the heparin-like action of PPS, i. e. potentiation of the activity of antithrombin III and/or heparin cofactor II. At

This work was financially supported by the "Centre de Recherches Clin-Midy" and "La Fondation de France".

\section{Abbreviations:}

S2238, H-D-phenylalanyl-L-pipecolyl-L-arginine-p-nitro-anilidedihydrochloride; S2337, N-benzoyl-L-isoleucyl-L-glutamyl-(piperidyl)glycyl-L-arginine-p-nitroanilide hydrochloride; RVV-X, Factor X activator purified from Russell's viper venom; Tris, tris(hydroxymethyl)aminomethane; EDTA, ethylenediaminotetraacetic acid; PC, phosphatidyl choline; PS, phosphatidyl serine; DOPC, 1,2-dioleoyl-sn-glycero3-phosphocholine; DOPS, 1,2-dioleoyl-sn-glycero-3-phosphoserine; STI, soybean trypsin inhibitor; HSA, human serum albumin; PPS, pentosan polysulphate (Hémoclar); MES, 2-(N-Morpholino)ethane sulfonic acid; DEAE, diethylaminoethyl; QAE, quaternary aminoethyl; SP, sulfopropyl; APTT, Activated partial thromboplastin time.

Correspondence to: Prof. Dr. H. C. Hemker, Department of Biochemistry, Biomedical Center, University of Limburg, P. O. Box 616, 6200 MD Maastricht, The Netherlands concentrations attained during therapeutic use the action of pentosan polysulphate on factor VIII $_{a}$ is the only one that will significantly inhibit the coagulation mechanism.

\section{Introduction}

Pentosan polysulphate (PPS) or Hémoclar ${ }^{\circledR}$ is a mixture of polysaccharides that is obtained by sulphation of pentosans extracted from beech wood shavings (2). Its average molecular weight is 4,500 (2). Soria et al. (3) and Scully et al. (4) have shown that PPS shows some similarities with low molecular weight heparin as to its inhibitory effect on blood coagulation. Both compounds are dependent upon antithrombin III for factor $\mathrm{X}_{\mathrm{a}}$ and thrombin inhibiting activities $(3,4)$. Pentosan polysulphate also is a good activator of heparin cofactor II (2). Apart from that, PPS inhibits the partial thromboplastin time independently of antithrombin III $(1,3)$. Dunn et al. (5) have shown that both heparin and PPS increase the binding of fibrinogen to ADPtreated platelets. Fischer et al. (1) showed that PPS inhibits the factor $\mathrm{X}_{\mathrm{a}}$ generation in defibrinated plasma triggered by contact activation as well as by purified factor $\mathrm{IX}_{\mathrm{a}}$. This suggests that PPS does not act on the contact system, but interferes with factor $\mathrm{X}$ activation at the level of factor $I_{\mathrm{a}}$. Both Ofosu et al. (6) and Walker and Esmon (7) have suggested that antithrombin III independent effects of heparin are due to inhibition of phospholipid binding. Fischer et al. (1) suggest that PPS acts by the same mechanism, presumably even more effective than heparin, because of its greater negative charge. Another suggested mechanism is inhibition of thrombin dependent factor $\mathrm{V}$ activation and thereby inhibiting the prothrombinase complex (8). From the literature it is clear that the site of inhibition of blood coagulation by PPS has not been determined unequivocally. Possible sites of action are: The activation of prothrombin by prothrombinase (factor $\mathrm{X}_{\mathrm{a}}$, factor $\mathrm{V}_{\mathrm{a}}$ and phospholipid) and the activation of factor $\mathrm{X}$ by its activating enzyme (factor $\mathrm{IX}_{\mathrm{a}}$, factor VIII $_{a}$ and phospholipid). This inhibition might be mediated by either impairment of the binding of clotting factors to phospholipids or direct action on thrombin in the activation of one more of the factors I, V, and VIII.

\section{Materials and Methods}

\section{Materials}

Human congenital factor VIII deficient plasma was a gift from $T$. Repucci, Centre de Transfusion, Liège, Belgium. The plasma was from a patient with less than $1 \%$ factor VIII. The blood $(450 \mathrm{ml})$ was collected in a bag containing CPDA-formula $1(63 \mathrm{ml}$, containing $2 \mathrm{~g}$ dextrose monohydrate, $1.66 \mathrm{~g}$ sodium citrate, $206 \mathrm{mg}$ citric acid, $158 \mathrm{mg}$ sodium acid phosphate, $17.3 \mathrm{mg}$ adenine). The blood was centrifuged at $5,000 \times \mathrm{g}$ during $15 \mathrm{~min}$ at $4^{\circ} \mathrm{C}$. The plasma was frozen at $-80^{\circ} \mathrm{C}$ before use. Bovine factors $V$ and $V_{a}$ were a gift from Dr. T. Lindhout. S2337, S2238, RVV-X and human fibrinogen (grade L) were purchased from AB Kabi Diagnostica, Stockholm, Sweden. STI, HSA (essentially fatty acid free), heparin (sodium salt) and Echis carinatus venom were obtained from Sigma. Sephadex G50, DEAE-Sephadex and SP-Sephadex were from 
Pharmacia, Trasylol was from Bayer. Actin activated cephaloplastin reagent was from Dade Diagnostics and Reptilase from Boehringer Mannheim. Hémoclar was a gift of the Laboratoires Clin Midy, Paris, France.

All other reagents used, were of the highest grade commercially available

\section{Proteins}

Bovine factor IX was purified according to Fujikawa et al. (9). Factor $\mathrm{IX}_{\mathrm{a}}$ was prepared by incubating bovine factor IX with purified contact product $(10,11)$ according to Fujikawa et al, (12)

Bovine factors $\mathrm{X}_{1}$ and $\mathrm{X}_{2}$ were prepared according to Fujikawa et al. (13). The two forms of factor $X$ were well separated. In this study factor $X_{1}$ is used, which is not indicated further. No thrombin or factor $X_{a}$ could be detected in our factor $\mathrm{X}$ preparations as determined with the chromogenic substrates S2238 and S2337, respectively. Bovine prothrombin was purified as described by Owen et al. (14). Thrombin was prepared by incubating $5 \mu \mathrm{M}$ prothrombin with $10 \mu \mathrm{M}$ phospholipid vesicles $(25 \%$ brain PS, $75 \%$ yolk PC), $10 \mathrm{mM} \mathrm{CaCl}, 30 \mathrm{nM}$ factor $\mathrm{X}_{\mathrm{a}}$ and $21 \mathrm{nM}$ factor $\mathrm{V}_{\mathrm{a}}$ during $40 \mathrm{~min}$ at $37^{\circ} \mathrm{C}$ in a buffer containing $40 \mathrm{mM}$ MES-Tris and $100 \mathrm{mM} \mathrm{NaCl}(\mathrm{pH} \mathrm{7.9)}$. The reaction was terminated with $20 \mathrm{mM}$ EDTA. Then the mixture was diluted twice with water, brought to $\mathrm{pH} 6.5$ with MES and applied to an SP-Sephadex column $(5 \times 40 \mathrm{~cm})$, which was equilibrated with $20 \mathrm{mM}$ Tris-MES amd $50 \mathrm{mM} \mathrm{NaCl}(\mathrm{pH} \mathrm{6.5)}$. The column was eluted with $250 \mathrm{ml}$ of $20 \mathrm{mM}$ Tris-MES, $200 \mathrm{mM} \mathrm{NaCl}$ ( $\mathrm{pH} 6.5$ ) to remove other prothrombin degradation products than thrombin. Finally the thrombin was eluted with a linear gradient of $(2 \times 500 \mathrm{ml})$ $200-2,000 \mathrm{mM} \mathrm{NaCl}$ in $20 \mathrm{mM}$ MES-Tris (pH 6.5). Thrombin fractions were dialysed against $175 \mathrm{mM} \mathrm{NaCl}$ and $50 \mathrm{mM}$ Tris-HCl (pH 7.9).

Bovine factor VIII was purified according to Vehar and Davic (15) with the modifications of Van Dieijen et al. (16). To standardize the factor VIII, reference curves were made, using congenital factor VIII deficient plasma and normal pooled bovine plasma (16).

\section{Protein Concentrations}

The molar concentrations of factors IX, IX,$X_{1}$, II, V, $V_{a}$ were calculated from their optical density at $280 \mathrm{~nm}$, their specific absorption and their molecular weight $(12,13,14,17)$.

The concentrations of activated clotting proteases also were determined spectrophotometrically from the amidolytic activity (18). Factor $\mathrm{X}$ was activated with $2 \mathrm{mg} / \mathrm{ml} \mathrm{RVV}$-X during $15 \mathrm{~min}$ at $37^{\circ} \mathrm{C}$ prior to functional measurement. Prothrombin was activated with Echis carinatus venom (19) and the ensuing thrombin was measured with S2238. Factor IX was activated with purified contact product $(10,11)$ and the factor IX $X_{\mathrm{a}}$ was measured according to Tans et al. (20).

Factors $\mathrm{V}$ and $\mathrm{V}_{\mathrm{a}}$ were determined according Lindhout et al. (21).

Factor VIII was measured in two ways: $\mathrm{A}$ and $\mathrm{B}$.

A: To a mixture of $200 \mu \mathrm{I}$ phospholipid vesicles $(30 \mu \mathrm{M}, 75 \%$ DOPC and $25 \%$ DOPS $), \mathrm{CaCl}_{2}(5 \mathrm{mM})$ and factor $\mathrm{IX}_{\mathrm{a}}(150 \mathrm{nM})$ were added $50 \mu \mathrm{l}$ factor $\mathrm{X}(2 \mu \mathrm{M})$ and $\mathrm{CaCl}_{2}(5 \mathrm{mM})$. Fifteen seconds after the addition of the factor $X$, the activated factor VIII was added $(50 \mu l)$. To stop the reaction samples of $200 \mu$ l were pipetted (after $20 \mathrm{sec}$ ) into $700 \mu \mathrm{l}$ $20 \mathrm{mM}$ EDTA (in a cuvette). The formed factor $X_{\text {a }}$ was measured by addition of $100 \mu \mathrm{l} S 2337(2 \mathrm{mM})$ and following substrate hydrolysis at $405 \mathrm{~nm}$. The whole procedure was done at $37^{\circ} \mathrm{C}$ and the mixtures used were prewarmed during at least $5 \mathrm{~min}$.

B: To a mixture of $250 \mu \mathrm{l} 40 \mu \mathrm{M}$ phospholipid vesicles (75\% DOPC and $25 \%$ DOPS), $10 \mathrm{mM} \mathrm{CaCl}_{2}, 100 \mathrm{nM}$ factor $\mathrm{IX}_{\mathrm{a}}$ were added $150-\mathrm{x} \mu \mathrm{l}$ buffer (see below). Then $\mathrm{x} \mu$ l factor $\mathrm{VIII}_{\mathrm{a}}$ were added and after $30 \mathrm{sec}$ $100 \mu \mathrm{l}$ factor $\mathrm{X}(2 \mu \mathrm{M})$ to start the reaction. After 30 and $60 \mathrm{sec}$ reaction time $200 \mu \mathrm{l}$-samples were taken and the formed factor $\mathrm{X}_{\mathrm{a}}$ was measured.

In all cases corrections were made for $\mathrm{S} 2337$ hydrolysis by thrombin and factor $\mathrm{X}_{\mathrm{a}}$ formation by factor $\mathrm{IX}_{\mathrm{a}}$ in the absence of factor VIII

All experiments with the purified clotting factors were performed in a buffer containing $175 \mathrm{mM} \mathrm{NaCl}, 50 \mathrm{mM}$ Tris- $\mathrm{HCl}, 0.5 \mathrm{mg} / \mathrm{ml}$ HSA (pH 7.9).

\section{Phospholipids and Phospholipid Vesicles}

DOPS was prepared from DOPC according to Comfurius and Zwaal (22). Vesicles were prepared by sonication of a phospholipid mixture of
25\% DOPS and 75\% DOPC using an MSE Mark II 150-Watt ultrasonic disintegrator, set at $9 \mu$ peak to peak amplitude, or by the ether-injection method according to Van de Steen et al. (23) and Deamer and Bangham (24). By injection of $2 \mathrm{ml}$ ether, containing $3 \mu \mathrm{mol} \mathrm{DOPC}$ and $1 \mu \mathrm{mol}$ DOPS into $4 \mathrm{ml}$ warm $\left(60^{\circ} \mathrm{C}\right)$ buffer $(175 \mathrm{mM} \mathrm{NaCl}, 50 \mathrm{mM}$ Tris- $\mathrm{HCl}$; $\mathrm{pH} 7.9)$ large unilamellar vesicles were obtained. The vesicles were dialyzed against the same buffer to remove traces of ether. To concentrate the vesicles and to remove small vesicles which cannot be spun down, they were centrifuged at $6,000 \times \mathrm{g}$ during $10 \mathrm{~min}$. The supernatant was discarded, the pellet suspended into the same buffer and again the vesicles were spun down. Finally the pellet was taken up into a small amount of buffer. These vesicles were used in the binding studies.

Phospholipid concentrations were determined by analysis of the phosphate content (25).

\section{Binding Experiments}

Binding of clotting factors to large unilamellar vesicles was measured in the following way. Clotting factors $(20-100 \mathrm{nM})$ were incubated in the presence of $5 \mathrm{mM} \mathrm{CaCl}_{2}$ with various concentrations of large-volumevesicles containing $25 \%$ DOPS and $75 \%$ DOPC. Then the vesicles were spun down $(10 \mathrm{~min}$ at $9,000 \times \mathrm{g})$ and the unbound clotting factors were measured in the supernatant.

\section{Clotting of Fibrinogen}

To $50 \mu \mathrm{l}$ human fibrinogen $(10 \mathrm{mg} / \mathrm{ml})$ were added $50 \mu \mathrm{l}$ buffer (175 mM NaCl, $50 \mathrm{mM}$ Tris- $\mathrm{HCl}(\mathrm{pH} 7.9), 0.5 \mathrm{mg} / \mathrm{ml} \mathrm{HSA}$ and if present $20 \mathrm{mM} \mathrm{CaCl}$ ). The reaction was started by the addition of $100 \mu \mathrm{l}$ thrombin (20-80 $\mathrm{nM})$. The clotting time was detected manually.

\section{Results}

\section{Binding Experiments}

In order to measure the effect of PPS on binding of clotting factors to phospholipid membranes we first determined the conditions under which without PPS, $50 \%$ of the factor would be bound. The effect of PPS on the binding of the different factors has been determined at a range of PPS concentrations $(0-20 \mu \mathrm{g} /$ $\mathrm{ml}$ ). In none of the cases PPS prevented binding of the clotting factor to the phospholipid membranes. PPS in many cases even slightly promotes this binding, an effect that is most pronounced for factors $X_{a}$ and $I X_{a}$. Table 1 shows the results for one PPS concentration. Because no inhibition of the binding could be shown under the above circumstances, the other data are not shown.

\section{Thrombin-Dependent Activation of Factors $V$ and VIII and Fibrinogen}

Fig. 1 shows the effect of PPS on the activation of factor VIII by $0.5 \mathrm{nM}$ thrombin. In the absence of PPS the maximal amount of factor $\mathrm{VIII}_{\mathrm{a}}$ is reached after about $3 \mathrm{~min}$ and then the amount slowly decreases. When PPS is present during the activation, the rate of factor $\mathrm{VIII}_{\mathrm{a}}$ formation strongly decreases with increasing PPS concentrations and the maximal amounts of factor VIII formed also are much lower. Half maximal inhibition of the activation is obtained at about $1 \mu \mathrm{g} / \mathrm{ml}$ of PPS. An amount of $0.5 \mathrm{nM}$ thrombin activates factor VIII only slowly. In Fig. 2 the factor VIII is activated with $50 \mathrm{nM}$ thrombin. The turnover numbers in both cases differ quite a lot. In Fig. 1 the number is 23-30 $\mathrm{min}^{-1}$, whereas it is in Fig. 2 about $800 \mathrm{~min}^{-1}$. From these numbers it can be calculated that after $1 \mathrm{~min}$ activation with $0.5 \mathrm{nM}$ thrombin not more than $2 \%$ of the factor VIII is activated.

The experiment of Fig. 1 is repeated with $2.5 \mathrm{mg} / \mathrm{ml}$ fibrinogen present in the factor VIII activating mixture. In that case the activation rate of factor VIII is decreased. To obtain a same 


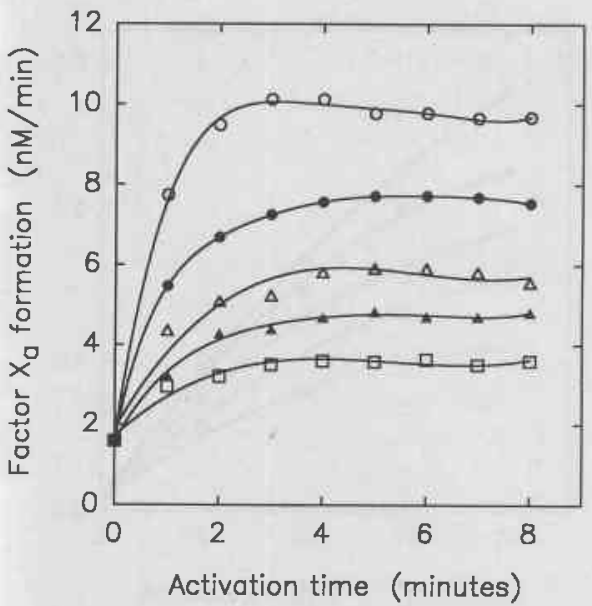

Fig, 1 Effect of PPS on the activation of factor VIII by thrombin. Factor VIII $(2 \mathrm{nM})$ was activated $\left(37^{\circ} \mathrm{C}\right)$ with $0.5 \mathrm{nM}$ thrombin in the presence of $5 \mathrm{mM} \mathrm{CaCl}_{2}$ and PPS in concentrations of $0(0), 0.5(\bullet), 1$ $(\triangle), 2(\Delta)$ and $4(\square) \mu \mathrm{g} / \mathrm{ml}$. The formed factor $V_{I I}$ was measured after 1-8 min activation time: procedure $\mathrm{A}$, see Methods. Corrections were made for the inhibiting effect of PPS on the factor X-activating reaction itself. To determine this effect, independently from the effect on factor VIII activation, PPS was added to the factor $\mathrm{X}$ activating mixture in the required concentrations. Then factor VIII $(2 \mathrm{nM})$, activated for $4 \mathrm{~min}$ $\left(37^{\circ} \mathrm{C}\right)$ in the absence of PPS, was added to the reaction mixture and the rate of factor $\mathrm{X}$ activation measured

activation rate as in the absence of fibrinogen, about 2.5 times more thrombin is necessary. However, also with fibrinogen present, PPS still is a very potent inhibitor of factor VIII activation; $0.5,1,2$ and $4 \mu \mathrm{g} / \mathrm{ml}$ PPS cause inhibition percentages

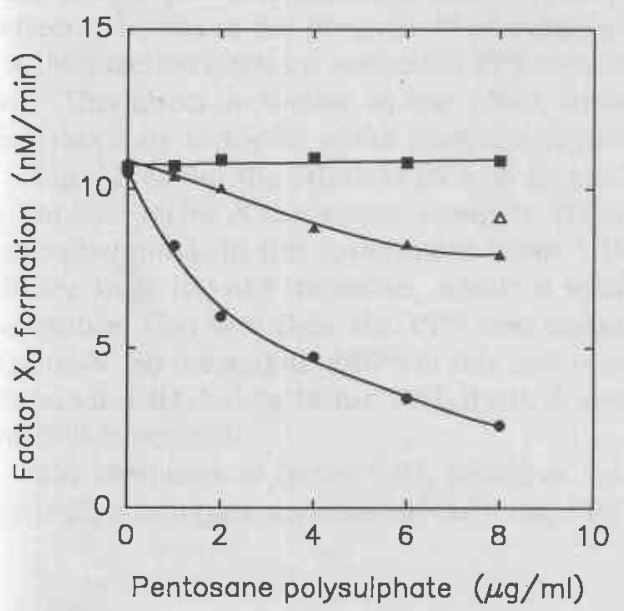

Fig. 2 Effect of PPS on activation of factor VIII with $50 \mathrm{nM}$ thrombin and effect of PPS on activated factor VIII. In case $(\boldsymbol{\Delta})$ the activation was started by mixing $20 \mu \mathrm{l}$ factor VIII $(12 \mathrm{nM})$ with $20 \mu \mathrm{l}$ thrombin $(100 \mathrm{nM}), \mathrm{CaCl}_{2}(10 \mathrm{mM})$. At $\mathrm{t}=30 \sec 20 \mu \mathrm{l}$ PPS $(0-24 \mu \mathrm{g} / \mathrm{ml})$ were added, making the final PPS concentrations as indicated in the figure. The PPS solution also contained $5 \mathrm{mM} \mathrm{CaCl}$ and $50 \mathrm{nM}$ thrombin to kcep these concentrations constant after PPS addition. In case (-) the activation was started by addition of PPS together with thrombin. To $40 \mu \mathrm{l}$ factor VIII $(6 \mathrm{nM})$ were added $20 \mu \mathrm{I} 150 \mathrm{nM}$ thrombin, $15 \mathrm{mM} \mathrm{CaCl}_{2}$ and $0-24 \mu \mathrm{g} / \mathrm{ml}$ PPS. In both cases at $t=60 \sec 5 \mu 1$-samples were taken and assayed for factor $\mathrm{VIH}_{\mathrm{a}}$ (Methods, procedure B). The open triangle $(\triangle)$ is the result of factor VIII activation with $50 \mathrm{nM}$ thrombin in the presence of $5 \mathrm{mM} \mathrm{CaCl}_{2}$ and absence of PPS during $30 \mathrm{sec}$. The control (प) shows an experiment in which $5 \mu$ l PPS $(0-8 \mu \mathrm{g} / \mathrm{ml})$ were added to the factor VIII, assay mixture and the factor VIII was activated with $50 \mathrm{nM}$ thrombin (in the presence of $5 \mathrm{mM} \mathrm{CaCl}_{2}$ ) during $60 \mathrm{sec}$
Table 1 The effect of PPS on binding of clotting factors to large volume phospholipid vesicles

\begin{tabular}{llcc}
\hline Factor & $\begin{array}{l}\text { Concentration } \\
(\mathrm{nM})\end{array}$ & $\begin{array}{l}\mathrm{C} 50 \\
(\mu \mathrm{M})\end{array}$ & $\begin{array}{l}\Delta \mathrm{B} \\
(\%)\end{array}$ \\
\hline $\mathrm{X}$ & 41 & 37 & +28 \\
$\mathrm{X}_{\mathrm{a}}$ & 59 & 17.5 & +37 \\
$\mathrm{IX}$ & 65 & 445 & +12 \\
IX $_{\mathrm{a}}$ & 58 & 63 & +35 \\
II & 31 & 45 & +4 \\
$\mathrm{~V}$ & 96 & 600 & -5 \\
$\mathrm{~V}_{\mathrm{a}}$ & 20 & 12.6 & +17 \\
VIII & 50 & 47 & +1 \\
\hline
\end{tabular}

C50 is the phospholipid concentration at which the binding of the clotting factors in the absence of PPS is $50 \%, \triangle \mathrm{B}$ is the change in binding brought about by $5 \mu \mathrm{g} / \mathrm{ml}$ PPS. The binding of the eight clotting factors to the vesicles was measured at a range of phospholipid concentrations to determine the phospholipid concentration that causes a $50 \%$ binding of the clotting factor. At these phospholipid concentrations the effect of PPS was determined. Five $\mu \mathrm{g}$ PPS per ml were added to phospholipid-clotting factor-mixtures and the effect of the PPS on the binding was determined.

of $20,39,64$ and 81 , respectively. These numbers are similar to the values found in Fig. 1.

Fig. 2 shows an experiment in which factor VIII is activated with $50 \mathrm{nM}$ thrombin for $1 \mathrm{~min}$. Two cases were compared, firstly PPS was added before the addition of thrombin and secondly it was added $30 \mathrm{sec}$ after the addition of thrombin. Factor $\mathrm{VIII}_{\mathrm{a}}$ was measured by diluting it 100 -fold in the factor $\mathrm{X}$ activating mixture ( $5 \mu$ l-sample). The control shows that the PPS present in the $5 \mu \mathrm{l}$ sample does not affect the factor VIII $_{\mathrm{a}}$-assay. When PPS is present during the whole minute it effectively inhibits, but when it is added at $30 \mathrm{sec}$ after the thrombin addition (then almost all factor VIII is activated; point $\triangle$ ) it has only a minimal effect. So we can conclude that PPS inhibits factor VIII activation, but hardly preformed factor $\mathrm{VIII}_{\mathrm{a}}$, provided that the PPS is diluted afterwards.

The effect of PPS on factor $V$ activation is shown in Fig. 3. One can observe that PPS has only a slight inhibitory effect. The effect of PPS on factor $\mathrm{V}$ activation by thrombin is, decreasing the activation rate and not inhibiting factor $V_{a}$. The factor $V_{a}$ activity after $2 \mathrm{~h}$ activation time was the same for all PPS concentrations. In Fig. 3 the plateau after $2 \mathrm{~h}$ was at $1.6 \mathrm{nM} \mathrm{min}^{-1}$. Half maximal inhibition requires more than $30 \mu \mathrm{g} / \mathrm{ml}$ of PPS.

The effect of PPS on fibrinogen clotting by thrombin was less then $20 \%$ under all conditions either in the absence or presence of $5 \mathrm{mM} \mathrm{CaCl}_{2}$. In the absence of $\mathrm{CaCl}_{2}, 10$ and $40 \mathrm{nM}$ thrombin caused clotting times of 196 and $119 \mathrm{sec}$, which were not prolonged by $50 \mu \mathrm{g} / \mathrm{ml}$ PPS and only for a few seconds with much higher PPS concentrations (up to $250 \mu \mathrm{g} / \mathrm{ml}$ ) representing an inhibition of less than $10 \%$. In the presence of $5 \mathrm{mM} \mathrm{CaCl}_{2}$, the clotting times were 152 and $39.5 \mathrm{sec}$, using 10 and $40 \mathrm{nM}$ thrombin, respectively. Also in this case PPS hardly had an effect. No change in the clotting times was observed at less than $20 \mu \mathrm{g} / \mathrm{ml}$ PPS and only some prolongation of the clotting time could be noticed at $50 \mu \mathrm{g} / \mathrm{ml}$ PPS: the above mentioned clotting times were 20 and $4 \mathrm{sec}$ longer, respectively, representing an inhibition of $10-20 \%$.

\section{The Effect of PPS of the Activation of Factors II and X}

We have studied the effect of PPS on the prothrombin activating complex. In the absence of phospholipid PPS has no effect on prothrombin activation, however, when phospholipids are present the activation reaction is somewhat stimulated by PPS (two-fold). PPS does not affect the complete prothrombin activat- 


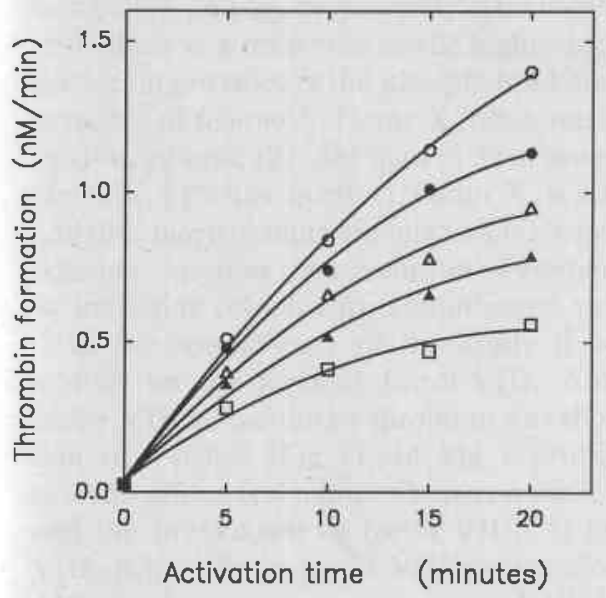

Fig. 3 The effect of PPS on activation of factor $\mathrm{V}$ by thrombin. Factor $\mathrm{V}$ $(42 \mathrm{nM})$ was activated with $0.5 \mathrm{nM}$ thrombin, in the presence of $5 \mathrm{mM}$ $\mathrm{CaCl}_{2}$ and PPS in concentrations of $0(0), 4(\bullet), 8(\triangle), 16(\Delta)$ and $32(\square)$ $\mu \mathrm{g} / \mathrm{ml}$. To stop further activation, the mixture was diluted 1,000 -fold in $5 \mathrm{mM} \mathrm{CaCl}_{2}$, before measuring the factor $\mathrm{V}_{\mathrm{a}}$ formed ing complex up to $4 \mu \mathrm{g} / \mathrm{ml}$ and a minor inhibiting effect is noticed (less than 20\%) at higher PPS concentrations. So in this case PPS does not stimulate the reaction rate as we found in the absence of factor $V_{\mathrm{a}}$.

In Fig. $4 \mathrm{~A}$ the effect of PPS on factor $\mathrm{X}$ activation by factor IX $X_{a}$ is shown, both in the absence of phospholipid vesicles and in their presence. In the absence of phospholipids there is no effect, whereas in the presence of phospholipids some activation of the reaction ( $80 \%$ ) is noticed at PPS concentrations of $4-8 \mu \mathrm{g} /$ $\mathrm{ml}$. This effect is similar to the effect found for prothrombin activation by factor $\mathrm{X}_{\mathrm{a}}$ in the presence of phospholipids.

Fig. 4B shows the effect of PPS on factor $X$ activation by the complete factor X activating complex (factors $\mathrm{IX}_{\mathrm{a}}, \mathrm{VIII}_{\mathrm{a}}$ and phospholipids). In this experiment factor VIII was activated for $30 \mathrm{sec}$ with $100 \mathrm{nM}$ thrombin, which is sufficient for complete activation (26) and then the PPS was added together with the factor X. So the action of PPS in this case is not on the activation of factor VIII, but on factor VIII itself. A strong inhibiting effect of PPS is noticed.

The inhibition of factor $\mathrm{VIII}_{\mathrm{a}}$ bound in the complete factor $\mathrm{X}$ activating complex depends on both the PPS concentration and

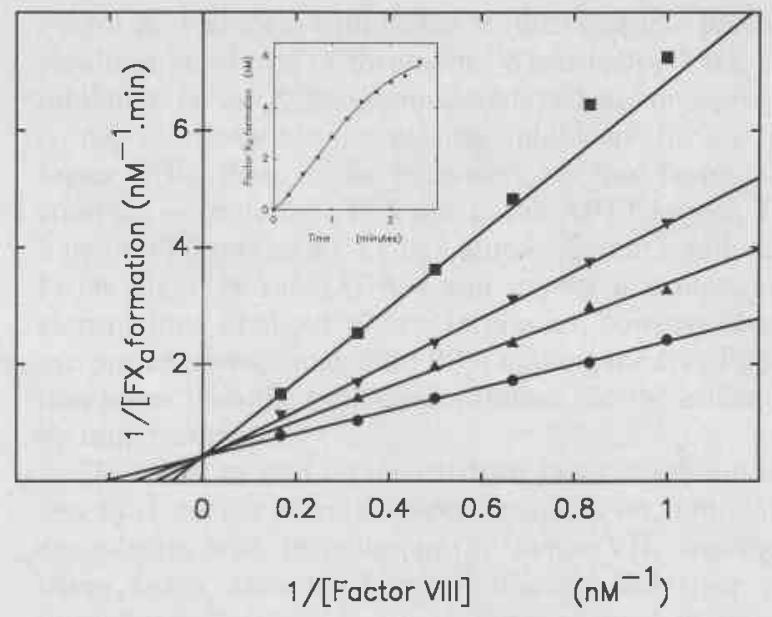

Fig. 5 Factor $\mathrm{X}$ activation by the complete factor $\mathrm{X}$ activating complex in the absence and presence of PPS. The reaction vessel contained $3 \mathrm{pM}$ factor $\mathrm{IX}_{2}, 5 \mathrm{mM} \mathrm{CaCl}, 20 \mu \mathrm{M}$ phospholipids, $100 \mathrm{nM}$ thrombin and PPS, present in concentrations of $0(\bullet), 0.5(\mathbf{\Delta}), 1(\boldsymbol{\nabla})$ and $2(\square) \mu \mathrm{g} / \mathrm{ml}$. Before starting the reaction all components were preincubated during $5 \mathrm{~min}$ at $37^{\circ} \mathrm{C}$. Then $0.2 \mu \mathrm{M}$ factor $\mathrm{X}$ was added $(\mathrm{t}=0 \mathrm{~min})$ and at $\mathrm{t}=$ $1 \mathrm{~min}$ the factor VIII (1-6 $\mathrm{nM}$, i.e. 1.45-8.72 U/ml). Samples were taken at $\mathrm{t}=1.25 \mathrm{~min}$ and assayed for factor $\mathrm{X}_{\mathrm{a}}$. The inset shows that factor $\mathrm{X}$ activation was linear from 5 to $90 \mathrm{sec}$ after the factor VIII addition. The $\mathrm{V}_{\max }$ was $2.406 \mathrm{nM} \mathrm{FX}_{\mathrm{a}} \min ^{-1}$

the factor VIII ${ }_{a}$ concentration as is shown in Fig. 5. Fig. 5 is a double reciprocal plot of the factor $\mathrm{X}_{\mathrm{a}}$ formation against the factor VIII concentration at different PPS concentrations. Straight lines were obtained, which all cross the $y$-axis at the same point $\left(0.416 \mathrm{nM}^{-1}\right.$ min, i.e. $2.406 \mathrm{nM}$ factor $\mathrm{X}_{\mathrm{a}}$ formed per min). Thus at infinite factor $\mathrm{VIII}_{\mathrm{a}}$ concentration PPS does not inhibit the complete factor $\mathrm{X}$ activating complex.

\section{Discussion}

The binding experiments described in this article show that in no case PPS prevents binding of a clotting factor to procoagulant phospholipids. So one may conclude that inhibiting effect of PPS in blood coagulation is not caused by preventing the formation of the prothrombin or factor $\mathrm{X}$ activating complexes. There even exists a stimulating effect of PPS on binding of factors $\mathrm{IX}_{\mathrm{a}}$ and $\mathrm{X}_{\mathrm{a}}$ and to a lesser extent on binding of factors IX, $X$ and $V_{a}$ to phospholipid membranes (Table 1), the reason for this phenomenon is not yet clear. This increased binding, moreover, leads to higher enzymatic activities. PPS stimulates - in the presence of phospholipids - the activation of factors X (Fig. 4A) and II by
Fig. 4 Effect of PPS on the factor $\mathrm{X}$ activation by factor $\mathrm{IX}_{\mathrm{a}}$. Frame A: Activation of factor $\mathrm{X}$ by factor $\mathrm{IX}_{\mathrm{a}}$ in the absence ( and presence $(\mathbf{\Delta})$ of phospholipids. The reaction mixture contained $1 \mu \mathrm{M}$ factor $\mathrm{IX}_{a}, 5 \mathrm{mM} \mathrm{CaCl}, 0-10 \mu \mathrm{g} / \mathrm{ml}$ PPS and if present $20 \mu \mathrm{M}$ phospholipids. In the absence of phospholipids the reaction was started with $8 \mu \mathrm{M}$ factor $\mathrm{X}$ and in their presence with $2 \mu \mathrm{M}$ factor X. Samples were taken after 10,20 and $30 \mathrm{~min}$ reaction time and assayed for factor $\mathrm{X}_{\mathrm{a}}$. Frame $\mathrm{B}$ : Activation of factor $\mathrm{X}$ by the complete factor $\mathrm{X}$ activating complex. The reaction mixture contained $50 \mathrm{nM}$ factor $\mathrm{IX}_{\mathrm{a}}, 100 \mathrm{nM}$ thrombin, $5 \mathrm{mM}$ $\mathrm{CaCl}_{2}, 20 \mu \mathrm{M}$ phospholipids, $15 \mathrm{pM}$ factor VIII (added at $\mathrm{t}=0$ sec) and $0-10 \mu \mathrm{g} / \mathrm{ml}$ PPS $+1 \mu \mathrm{M}$ factor $\mathrm{X}$, which were added together at $t=30 \mathrm{sec}$. Samples were taken at $t=60$ and $90 \mathrm{sec}$ and assayed for factor $\mathrm{X}_{\mathrm{a}}$. In all cases before starting the reaction of the components were preincubated at $37^{\circ} \mathrm{C}$ for $5 \mathrm{~min}$

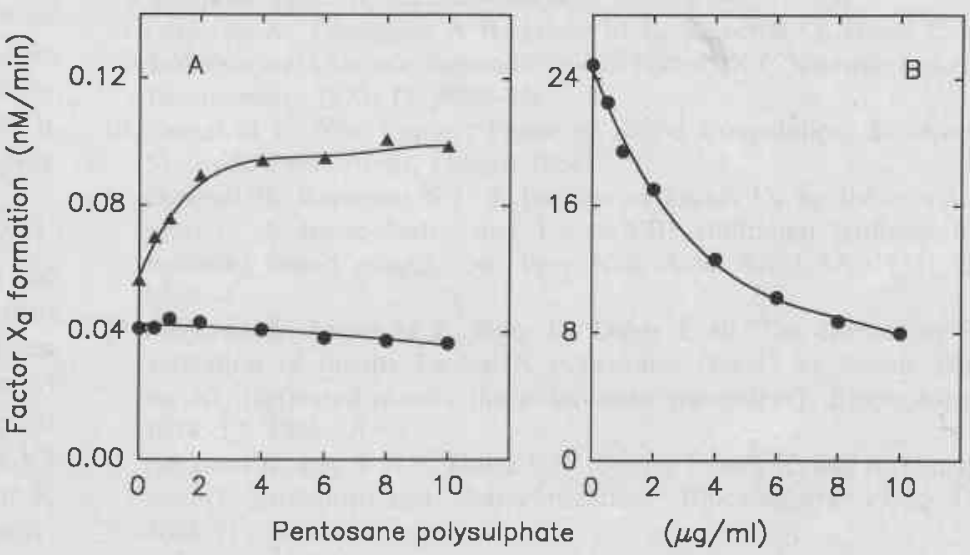


factors $\mathrm{IX}_{\mathrm{a}}$ and $\mathrm{X}_{\mathrm{a}}$, respectively. The increased enzymatic activity very likely is a reflection of the higher local concentration of the activation enzyme on the phospholipid membrane surface. In the presence of factor $\mathrm{V}_{\mathrm{a}}$, factor $\mathrm{X}_{\mathrm{a}}$ binds much tighter to a phospholipid membrane $(27,28)$ than in its absence, so in the presence of factor $V_{a}$ PPS has no effect: factor $X_{a}$ is almost completely bound and thus more binding leading to a higher enzymatic activity is not possible. Anyhow the conclusion of Fischer et al. (1) that PPS acts by inhibiting complex formation seems to be refuted.

In the second part of this study it became clear that PPS inhibits on the level of factor VIII. About $85 \%$ inhibition of factor VIII activation by thrombin was shown at a PPS concentration of $4 \mu \mathrm{g} / \mathrm{ml}$ (Fig. 1). In Fig. 1 probably an equilibrium is reached after a few minutes between the formation of factor $\mathrm{VIII}_{\mathrm{a}}$ and the breakdown of factor $\mathrm{VIII}_{\mathrm{a}}$. If the formation of factor VIII $_{\mathrm{a}}$ from a large factor VIII pool is slow, than the large pool does not decrease in size, so factor $\mathrm{VIII}_{\mathrm{a}}$ formation will continue for several minutes with the same speed. In that case a plateau is reached depending on formation and breakdown of factor $\mathrm{VIII}_{\mathrm{a}}$. When factor VIII formation is diminished, two effects may be noticed, the initial rate of factor $\mathrm{VIII}_{\mathrm{a}}$ formation is lower and the plateau is on a lower level. So PPS has two effects, it decreases the initial activation rate and it causes a lower steady state level of factor VIII $_{a}$.

The data from Fig. 1 may be interpreted in two ways. Either factor VIII $_{\mathrm{a}}$ is inhibited by PPS or the activation of factor VIII by thrombin is inhibited by this drug. Fig. 2 shows that PPS inhibits factor VIII activation by thrombin, but does not inactivate preformed factor $\mathrm{VIII}_{\mathrm{a}}$. Combining the results of Figs. 2 and 4B it is clear that although PPS does not inactivate factor $\mathrm{VIII}_{\mathrm{a}}$, it inhibits the function of factor VIII $_{a}$. Factor VIII $_{a}$ probably is reversibly inhibited by binding to PPS. When a PPS-factor VIII $_{a}$ complex is diluted sufficiently (100-fold, Fig. 2) factor $\mathrm{VIII}_{\mathrm{a}}$ gets back its function.

Factor $\mathrm{V}$ activation by thrombin also can be inhibited by PPS, however, about 30-fold higher concentrations of PPS are required to obtain the same inhibiting effect (Fig. 3). Clotting of fibrinogen by thrombin is hardly inhibited and only then when the PPS concentration is very high. Probably there is no interaction between fibrinogen and PPS, for, as was shown, fibrinogen does not prevent the inhibitory effect of PPS on factor VIII activation by thrombin.

In Figs. 4-5 we showed the effect of PPS on the complete and incomplete factor $\mathrm{X}$ activating complex. The most important result is the inhibiting effect of PPS on the complete factor $\mathrm{X}$ activating complex (Fig, 4B). Under the conditions of Fig. 4B half maximal inhibition is caused by $4 \mu \mathrm{g} / \mathrm{ml} \mathrm{PPS}$, but from Fig. 5 it is clear that the percentage of inhibition depends on both the PPS concentration and the factor $\mathrm{VIII}_{\mathrm{a}}$ concentration. On extrapolation to infinite factor VIII $\mathrm{a}_{\mathrm{a}}$ concentration no inhibition is found at any PPS concentration, which means that it is not the factor $X$ activating complex as such that is inhibited by PPS, but one of its components: factor VIII $_{\mathrm{a}}$. When factor VIII $_{\mathrm{a}}$ is present in excess no inhibition of the complex by PPS is found. Thus PPS has a twofold effect, it inhibits factor VIII activation by thrombin and it inhibits factor VIII $_{\mathrm{a}}$ action in the factor $\mathrm{X}$ activating complex probably by reversible binding to factor VIII $_{\mathrm{a}}$.

On basis of the result that PPS mainly acts on factor VIII $_{\mathrm{a}}$ activation, one can predict that PPS should have an effect on the APTT. On starting blood coagulation by contact activation factor $\mathrm{XI}_{\mathrm{a}}$ activates factor IX, factor $\mathrm{IX}_{\mathrm{a}}$ then slowly activates factor $\mathrm{X}$ and finally factor $\mathrm{X}_{\mathrm{a}}$ slowly activates prothrombin to thrombin, which initially is formed in trace amounts. These small amounts of thrombin activate factor VIII (and also factor V) slowly. When some factor $\mathrm{VIII}_{\mathrm{a}}$ is present, the complete factor $\mathrm{X}$ activating complex is formed, which will activate factor $\mathrm{X}$ rapidly.
Factor $\mathrm{X}_{\mathrm{a}}$ will form with factor $\mathrm{V}_{\mathrm{a}}$ the complete prothrombinase, resulting in a burst of thrombin. When factor $\mathrm{VIII}_{\mathrm{a}}$ formation is inhibited, factor $\mathrm{X}_{\mathrm{a}}$ formation is delayed and moreover factor $\mathrm{IX}_{\mathrm{a}}$ is more susceptible to plasma inhibitors in the absence of factor VIII $_{a}$ than in its presence, so less factor $\mathrm{X}$ activating complex is formed. So PPS makes the APTT longer. The effect of $2 \mu \mathrm{g} / \mathrm{ml}$ PPS on the APTT in a human system is not very high (3). From Fig. 1 in ref. (3) one can expect a prolongation of the clotting time of about $10 \mathrm{sec}$. In plasma, however, many proteins are present, which may bind PPS, making the free PPS concentration lower than the total concentration. So the effect of PPS may be underestimated.

The effect of PPS on the extrinsic blood coagulation should be less than on the intrinsic blood coagulation. On starting blood coagulation with thromboplastin, factor $\mathrm{VII}_{\mathrm{a}}$ together with the tissue factor activates factor $\mathrm{X}$ directly and trace amounts of thrombin will activate factor $V$ (not very much inhibited by PPS), so the complete prothrombinase is formed independently of the factor $\mathrm{X}$ activating complex.

We conclude that the main antithrombin III independent inhibitory action of PPS is due to its effects on factor $\mathrm{VIII}_{\mathrm{a}}$. Therapeutic concentrations of PPS will not rise higher than $2 \mu \mathrm{g} /$ $\mathrm{ml}$ (1) and at this concentration the only antithrombin III independent action on blood coagulation is that on factor $\mathrm{VIII}_{\mathrm{a}}$.

\section{References}

1 Fischer A M, Barrowcliffe T W, Thomas D P. A Comparison of pentosan polysulphate (SP 54) and heparin. I: Mechanism of action on blood coagulation. Thromb Haemostas 1982; 47: 104-8.

2 Scully M F, Ellis V, Kakkar V V. Pentosan polysulphate: Activation of heparin cofactor II or antithrombin III according to molecular weight fractionation. Thromb Res 1986; 41: 489-99.

3 Soria C, Soria J, Rijckewaart J J, Holmer E, Caen J P. Anticoagulant activities of a pentosane polysulphate: Comparison with standard heparin and a fraction of low molecular weight heparin. Thromb Res 1980; 19: 455-63.

4 Scully M F, Weerasinghe K M, Ellis V, Djazaeri B, Kakkar V V. Anticoagulant and antiheparin activities of a pentosan polysulphate. Thromb Res 1983; 31: 87-97.

5 Dunn F, Soria J, Soria C, Thomaidis A, Tobelem G, Caen P. Fibrinogen binding on human platelets. Influence of different heparins and pentosane polysulphate. Thromb Res 1983; 29: 141-8.

6 Ofosu F, Blajchman M A, Hirsh J. The inhibition by heparin of the intrinsic pathway activation of factor $\mathrm{X}$ in the absence of antithrombin III. Thromb Res 1980; 20: 391-403.

7 Walker F J, Esmon C T. Interactions between heparin and factor $X_{a}$. Inhibition of prothrombin activation. Biochim Biophys Acta 1979 585: 405-15.

8 Ofosu F A, Sie P, Modi G J, Fernandez F, Buchanan M R, Blajchman M A, Boneu B, Hirsh J. The inhibition of thrombin dependent positive-feedback reactions is critical to the expression of the anticoagulant effect of heparin. Biochem J 1987; 243: 579-88.

9 Fujikawa $\mathrm{K}$, Thompson A R, Legaz M E, Meyer R G, Davie E W. Isolation and characterization of bovine Factor IX (Christmas factor). Biochemistry 1973; 12: 4938-45.

10 Nossel H L. The Contact Phase of Blood Coagulation. Blackwell Scientific Publications, Oxford 1964.

11 Østerud B, Rapaport S I. Activation of Factor IX by the reaction product of tissue factor and Factor VII: additional pathway for initiating blood coagulation. Proc Natl Acad Sci USA 1974; 12 : $5260-4$.

12 Fujikawa K, Legaz M E, Kato H, Davie E W. The mechanism of activation of bovine Factor IX (Christmas factor) by bovine Factor $\mathrm{XI}_{\mathrm{a}}$ (activated plasma thromboplastin antecedent). Biochemistry 1974; 13: 4508-16.

13 Fujikawa K, Legaz M E, Davie E W. Bovine Factor $X_{1}$ and $X_{2}$ (Stuart factor). Isolation and characterization. Biochemistry 1972; 11 : $4882-91$. 
14 Owen W G, Esmon CT, Jackson CM. The conversion of prothrombin to thrombin. I. Characterization of the reaction products formed during the activation of bovine prothrombin. J Biol Chem 1974; 249: 594-605.

15 Vehar G A. Davis E W. Preparation and properties of bovine factor VIII (antihemophilic factor). Biochemistry 1980; 19: 401-10.

16. Van Dieijen G, van Rijn J L M L, Govers-Riemslag J W P. Hemker H C, Rising J. Assembly of the intrinsic factor $\mathrm{X}$ activating complex: Iterations between factor $\mathrm{IX}_{u}$, factor $\mathrm{VIII}_{\alpha}$ and phospholipid. Thromb Haemostas 1985; 53: 396-400.

17 Nesheim E M, Myrmel K H, Hibbard L, Mann K G. Isolation and characterization of single chain bovine Factor V. J Biol Chem 1979; 254: 508-17.

18 Lottenberg R, Christensen U, Jackson C M, Coleman P L. Assay of Coagulation Proteases Using Peptide Chromogenic and Fluorogenic Substrates. In: Methods in Enzymology. Lorand L (ed). 1981; 80: 341-61.

19 Van de Wart P, Bruls H, Hemker H C, Lindhout T. Interactions of Bovine Blood Clotting Factor $V_{a}$ and Its Subunits with Phospholipid Vesicles. Biochemistry 1983; 22: 2427-32.

20 Tans G, Janssen-Claessen T, van Dieijen G, Hemker H C, Losing J. Activation of Factor IX by Factor $\mathrm{XI}_{\mathrm{a}}-\mathrm{A}$ spectrophotometric assay for Factor IX in human plasma. Thromb Haemostas 1982; 48: 127-32.

21 Lindhout T, Govers-Riemslag J W P, Van de Wart P, Rising J, Hemker H C. Factor $V_{\text {a }}$ - Factor $X_{u}$ interaction. Effects of pos- pholipid vesicles of varying composition. Biochemistry 1982; 21: 5494-502.

22 Comfurius P, Zwaal R F A. The enzymatic synthesis of phosphatidyl serine and purification by CM-cellulose column chromatography. Biochim Biophys Acta 1977; 488: 36-42.

23 Van der Steen A T M, De Jung W A C, De Kruijff B, Van Deenen L L M. Lipid dependence of glycophorin-induced transbilayer movement of lysophosphatidyl choline in large unilamellar vesicles. Biochim Biophys Acts 1981; 647: 63-72.

24 Delmer D, Bingham A D. Large volume liposomes by an ether vaporization method. Biochim Biophys Acta 1976; 443: 629-34.

25 Botcher C J F. Van Gent C M, Pries C. A rapid and sensitive submicrophosphorus determination. Anal Chm Act 1961:24:203-7.

26 Baruch D, Lindhout T, Wagenvoord R, Hemker H C. Inhibition of Thrombin Catalyzed Reactions in Blood Coagulation and Platelet Activation by Heparin Fractions in the Absence of Antithrombin III. Haemostasis 1986: 16: 71-81.

27 Nelsestuen G L, Broderius M. Interaction of prothrombin and blood clotting Factor X with membranes. Biochemistry 1977; 16: 4172-7.

28 Bloom J W, Nesheim M E, Mann K G. Phospholipid binding properties of bovine Factor $\mathrm{V}$ and Factor $\mathrm{V}_{\mathrm{a}}$. Biochemistry 1979; 18: 4419-25.

Received January 14, 1988 Accepted after revision May 31, 1988 